\title{
AGA Technical Review on Irritable Bowel Syndrome
}

\author{
This literature review and the recommendations therein were prepared for the American Gastroenterological Association Clinical \\ Practice Committee. The paper was approved by the Committee on August 5, 2002 and by the AGA Governing Board on September \\ 13, 2002.
}

$\mathrm{T}$ he irritable bowel syndrome (IBS) is part of the larger group of functional gastrointestinal (GI) disorders that, despite differences in location and symptom patterns, share common features with regard to their motor and sensory physiology, central nervous system (CNS) relationships, and the approach to patient care. ${ }^{1}$ IBS is a functional bowel disorder characterized by symptoms of abdominal pain or discomfort that is associated with disturbed defecation. ${ }^{2}$ This disorder is highly prevalent and can be associated with significant emotional distress, impaired health-related quality of life (HRQL), disability, and high health care costs. Psychosocial factors, although not part of IBS per se, have an important role in modulating the illness experience and its clinical outcome. ${ }^{3}$

Knowledge of the pathophysiology of IBS and the diagnosis and management of patients has previously been hampered by few well-designed investigations, a lack of diagnostic precision, and an absence of specific treatments. In the last 5 years, since publication of the previous AGA Technical Review on IBS, ${ }^{4}$ there has been a notable increase in basic, mechanistic, and clinical investigations that has improved our understanding of this disorder and its physiological and psychosocial determinants. The adoption of multinational symptombased criteria, ${ }^{1}$ particularly for clinical research studies, has increased diagnostic precision, and within clinical practice, may lead to a reduction in unneeded diagnostic studies. Finally, treatment methods have evolved toward use of more integrated multicomponent pharmacological and behavioral strategies based on the severity of, and psychosocial factors, influencing the patient's symptom pattern.

This technical review updates our previous report. ${ }^{4}$ Based on a critical review and analysis of the existing literature, we address: (1) the epidemiology and impact of the disorder, (2) its pathophysiological determinants, (3) the role of psychosocial factors in symptom experience and behavior, (4) the diagnostic approach, and (5) recommendations for treatment.

\section{Definition and Classification}

The Rome classification system ${ }^{1}$ characterizes the IBS in terms of multiple physiological determinants contributing to a common set of symptoms rather than a single disease entity. It is defined as a "group of functional bowel disorders in which abdominal discomfort or pain is associated with defecation or a change in bowel habit, and with features of disordered defecation."2,3 Table 1 lists the recently revised Rome II diagnostic criteria for IBS. ${ }^{1}$

\section{Epidemiology}

Prevalence

Table 2 gives the prevalence estimates for IBS from population surveys among American, European, and Australia/New Zealand adults. These prevalence estimates vary due to the diversity of definitional criteria and to differences in the specific questions used to elicit the information. There is also evidence that survey recall rates for reporting bowel symptoms are frequently inaccurate $^{5}$ and are strongly influenced by anxiety. ${ }^{6}$

The data from Table 2 may be summarized as follows: (1) the prevalence of IBS is greater in women; (2) the first presentation of patients to a physician is between the ages of 30 and 50 years, and there is a decrease in reporting frequency among older subjects; and (3) the prevalence seems to be similar in whites and blacks, but may be lower in Hispanics. Sandler's analysis of the NHANES data ${ }^{27}$ shows a 5 -fold greater prevalence of IBS in whites than blacks. However, this was based on self-report rather than symptom criteria or may have been influenced by limited access to health care by blacks. The overall prevalence was $2.9 \%$. However, epidemiological studies of non-European American and non-Western ethnic groups are limited and may be confounded by cultural influences. Available studies suggest that IBS seems to be as common in Japan, China, South America, and the Indian subcontinent as it is in

Abbreviations used in this paper: FDA, Food and Drug Administration; GI, gastrointestinal; HRQL, health-related quality of life; IBS, irritable bowel syndrome; PI-IBS, postinfectious irritable bowel syndrome; SSRI, selective serotonin reuptake inhibitor; TCA, tricyclic antidepressant.

(C) 2002 by the American Gastroenterological Association 0016-5085/02/\$35.00 doi:10.1053/gast.2002.37095 
Table 1. Rome II Diagnostic Criteria for Irritable Bowel Syndrome ${ }^{3}$

At least 12 weeks, which need not be consecutive, in the preceding 12 months of abdominal discomfort or pain that has 2 of 3 features:

1. Relieved with defecation; and/or

2. Onset associated with a change in frequency of stool; and/or

3. Onset associated with a change in form (appearance) of stool.

Symptoms that cumulatively support the diagnosis of IBS:

1. Abnormal stool frequency (for research purposes, "abnormal" may be defined as greater than 3 bowel movements per day and less than 3 bowel movements per week);

2. Abnormal stool form (lumpy/hard or loose/watery stool);

3. Abnormal stool passage (straining, urgency, or feeling of incomplete evacuation);

4. Passage of mucus;

5. Bloating or feeling of abdominal distention.

NOTE. The diagnosis of a functional bowel disorder always presumes the absence of a structural or biochemical explanation for the symptoms.

Western countries. ${ }^{3}$ There are limited data to address incidence rates.

\section{Symptom Features}

In the short term (weeks to months), the symptoms of IBS occur frequently. In a study of 59 patients in the United States, England, and the Netherlands, the majority reported at least one GI symptom on over one half of the days, and pain was reported one third of the time. ${ }^{7}$ Symptom episodes (defined as a period of symptoms bounded by symptom-free days) occurred 12.4 times during the 12 weeks of observation and averaged 5 days/episode.

Over a longer period of time (years), the symptoms of IBS wax and wane. When the prevalence of IBS is examined in the same population at 2 time points separated by 12 months $^{8}$ or 5 years, ${ }^{9}$ the point prevalence remains almost unchanged. However, up to $40 \%$ of subjects reporting symptoms at time 1 lose them at time 2 , only to be replaced by new cases at time 2 .

\section{Health Care Utilization and the Health Care Burden}

In the United States, up to $70 \%$ of persons with IBS symptoms do not seek medical attention. ${ }^{10,11}$ This may relate to cultural factors, ${ }^{12}$ the presence and degree of pain, ${ }^{13-17}$ and psychological disturbance. ${ }^{14,18}$ However, these rates are also influenced by access to health care. In the United States, where up to $40 \%$ of patients do not have easy access to health care, the consulting rate is $46 \%,{ }^{17}$ whereas in Australia, where health care access is close to $100 \%$, the consulting rate is $73 \% .{ }^{19}$ IBS accounts for $12 \%$ of patients seen in primary care prac- tice and is the largest diagnostic group seen in GI practice. Two surveys of AGA members ${ }^{20,21}$ undertaken 10 years apart show that functional GI disorders comprised respectively $41 \%$ and $35 \%$ of symptomatic outpatients' diagnoses, and IBS was the most frequent of the functional GI diagnoses.

Patients with IBS, when compared with persons with IBS not seeking health care or persons without bowel symptoms, have more non-GI complaints and consult physicians more for these symptoms. ${ }^{13,22,23}$ Female patients with IBS are 3 times as likely to receive a hysterectomy ${ }^{24}$ and report more surgical procedures such as appendectomies. ${ }^{25}$ In the U.S. Householder Study, ${ }^{17}$ persons with IBS visited physicians 1.64 times in the year before the survey for GI and 3.88 times for non-GI complaints, compared with 0.09 and 1.77 times, respectively, for persons without bowel symptoms.

Although most persons with IBS do not consult physicians, the cost to society in terms of direct medical expenses and indirect costs, such as work absenteeism, is considerable: (1) they miss 3 times as many work days as those without bowel symptoms (13.4 days vs. 4.9 days) and are more likely to report that they are too sick to work $(11.3 \% \text { vs. } 4.2 \%)^{17}$; (2) there are between 2.4 and 3.5 million physician visits annually for IBS in the United States, ${ }^{26,27}$ during which 2.2 million prescriptions are written ${ }^{27}$; and ( 3 ) they incur health care costs of \$4044 (1995 dollars), compared with \$2719 for those without IBS over the previous year. ${ }^{23}$ In a comprehensive assessment of burden of illness for GI illnesses in the United States, IBS was second only to esophageal reflux disease in its prevalence ( 15.4 million people) and was associated with $\$ 1.6$ billion in direct and $\$ 19.2$ billion in indirect costs. ${ }^{28}$ By adding 3.5 million people suffering from chronic diarrhea, the prevalence for lower functional bowel disorders nears that of gastroesophageal reflux disease. ${ }^{28}$ These data have important implications with regard to the need to identify treatments that can help improve HRQL and associated costs to society among a very large clinical population.

\section{Pathophysiology of IBS Symptoms}

The physiological mechanisms responsible for abdominal pain and altered bowel habits occur in healthy control subjects and in persons with IBS. Symptoms can occur in response to a disruption of functioning of the GI tract from an infection, dietary indiscretions (e.g., increased fat or alcohol intake), lifestyle changes (e.g., traveling or vigorous physical activity), or psychologic stress. Among college students and hospital employees, $71 \%$ reported that stresses affected their bowel pattern, 
Table 2. Epidemiological Studies of IBS in Western Countries Using Symptom Criteria

\begin{tabular}{|c|c|c|c|c|c|c|c|}
\hline \multirow[b]{2}{*}{ Source } & \multirow[b]{2}{*}{ Group characteristics } & \multirow[b]{2}{*}{ Sample size } & \multirow[b]{2}{*}{ Age (yrs) } & \multirow{2}{*}{$\begin{array}{l}\text { Diagnostic } \\
\text { criteria }\end{array}$} & \multicolumn{3}{|c|}{$\%$ IBS } \\
\hline & & & & & Total & Females & Males \\
\hline \multirow[t]{2}{*}{ Talley et al. ${ }^{15}$} & \multirow{2}{*}{$\begin{array}{l}\text { Olmsted County, MN } \\
\quad \text { white }=99 \%\end{array}$} & \multirow{2}{*}{$\begin{array}{l}\mathrm{N}=835 \\
\quad \text { Response }=82 \%\end{array}$} & \multirow{2}{*}{$\begin{array}{l}50 \\
\quad \text { Range 30-64 }\end{array}$} & $\geq 3$ Manning Sx & 12.8 & 13.6 & 12.1 \\
\hline & & & & $\geq 2$ Manning Sx & 17.0 & 18.2 & 15.8 \\
\hline Heaton et al. ${ }^{16}$ & $\begin{array}{l}\text { English urban } \\
\qquad \text { white }=99 \%\end{array}$ & $\begin{array}{l}\mathrm{N}=1896 \\
\quad \text { Response }=72 \%\end{array}$ & $\begin{array}{r}\text { Female } 25-69 \\
\text { Male } 40-69\end{array}$ & $\geq 3$ Manning Sx & 9.5 & 13.0 & 5.0 \\
\hline $\begin{array}{l}\text { Jones and } \\
\text { Lydeard } 225\end{array}$ & $\begin{array}{l}\text { Southern English } \\
\text { mostly white }\end{array}$ & $\begin{array}{l}\mathrm{N}=1620 \\
\quad \text { Response }=71 \%\end{array}$ & $20-90$ & $\geq 2$ Manning Sx & 21.6 & 24.3 & 18.7 \\
\hline Drossman et al. ${ }^{17}$ & $\begin{array}{l}\text { U.S. householder } \\
\text { white }=95 \% \\
\text { female }=51 \%\end{array}$ & $\begin{array}{l}N=5430 \\
\quad \text { Response }=66 \%\end{array}$ & $49 \pm 16$ & Rome I & 9.4 & 14.5 & 7.7 \\
\hline Kay et al. ${ }^{9}$ & $\begin{array}{l}\text { Copenhagen sex } \\
\text { stratified }\end{array}$ & $\begin{array}{l}N=3608 \\
\quad \text { Response }=79 \%\end{array}$ & Age stratified & $\begin{array}{l}\text { Altered bowel } \\
\text { habits and } \\
\text { pain relieved } \\
\text { by defecation }\end{array}$ & 6.6 & 7.7 & 5.6 \\
\hline \multirow[t]{2}{*}{ Zuckerman et al.226 } & $\begin{array}{l}\text { El Paso, TX } \\
\quad \text { white }=36 \%\end{array}$ & $\begin{array}{l}\mathrm{N}=905 \\
\quad \text { Response }=99 \%\end{array}$ & $30.5 \pm 9.3$ & $\begin{array}{c}\text { Drossman } \\
\text { criteria }\end{array}$ & $\begin{array}{l}16.9 \\
\text { Hispanics }\end{array}$ & 21.7 & 7.1 \\
\hline & $\begin{array}{l}\text { Hispanic }=64 \% \\
\text { female }=66 \%\end{array}$ & & & & $\begin{array}{l}21.8 \\
\text { white }\end{array}$ & 26.5 & 13.9 \\
\hline Taub et al. 227 & $\begin{array}{l}\text { U.S. college students } \\
\text { black }=26.9 \%\end{array}$ & $\begin{array}{l}\mathrm{N}=1344 \\
\quad \text { Response }=87 \%\end{array}$ & $21.2 \pm 5.6$ & $\geq 3$ Manning Sx & $\begin{array}{l}16.9 \\
\text { black }\end{array}$ & 19.1 & 9.7 \\
\hline & female $=62 \%$ & & & & $\begin{array}{l}15.0 \\
\text { white }\end{array}$ & 18.0 & 9.1 \\
\hline Osterberg et al. ${ }^{228}$ & Stockholm & $2707(54)$ & 31.5 (31.3-31.8) & Rome I & 10.6 & 13.3 & 7.4 \\
\hline Boyce et al.229 & Sydney & $2910(72)$ & $43.8(43.2-44.3)$ & Manning & 13.6 & 17.2 & 9.8 \\
\hline & & & & Rome I & 4.4 & 6.4 & 2.2 \\
\hline & & & & Rome II & 6.9 & 9.2 & 4.6 \\
\hline Talley et al. ${ }^{230}$ & Dunedin & $890(86)$ & Longitudinal study & $\geq 2$ Manning & 12.7 & 14.6 & 10.8 \\
\hline & & & (ages 3-26) & Rome II & 4.3 & 5.3 & 3.3 \\
\hline Thompson et al. 231 & Canada & $1149(57)$ & Weighted age & Modif Rome II & 12.1 & 15.2 & 8.7 \\
\hline & & & $\begin{array}{l}\text { sample (18 to } \\
>64 \text { ) }\end{array}$ & Rome I & 13.5 & 18.1 & 8.5 \\
\hline
\end{tabular}

and $54 \%$ reported that stress led to abdominal pain or discomfort. ${ }^{10}$

\section{Abnormal Motility in Patients With IBS}

Table 3 details the studies of altered GI motility in IBS and is summarized below. The differences between IBS patients and healthy controls are quantitative rather than qualitative.

Motility observations in the stomach, small intestine, colon, and rectum are qualitatively similar to those in healthy controls. Moreover, only $25 \%-75 \%$ of IBS patients exhibit the motility "abnormalities" listed in Table 3, which are considered to differentiate IBS from healthy controls. These motility parameters cannot be used as diagnostic markers.

In the ileum, colon, and rectum, IBS patients show an exaggerated response to a variety of provocative stimuli including meals, distention, stress, cholecystokinin, neostigmine, and corticotropin-releasing hormone injection. No corresponding pattern of hyper-reactivity has been shown in the proximal small intestine and stomach, where the response to stress (inhibition of contractions) differs from the response to meals (increase in contractions).

There is no consensus on the patterns of motility responsible for diarrhea and constipation, although accelerated transit is seen in diarrhea and slowed transit is seen in constipation. Among IBS patients exhibiting diarrhea and abdominal pain, there are significantly more high-amplitude propagating contractions, which are of higher amplitude than those observed in healthy controls, and these high-amplitude propagating contractions are more likely to be associated with a sensation of pain.

Motility abnormalities may interact with low sensory thresholds to produce symptoms: delayed transit of gas causes greater abdominal perception in IBS, ${ }^{29}$ and IBS patients are more likely than healthy controls to perceive the occurrence of normal migrating motor complexes. ${ }^{30}$

\section{Visceral Hypersensitivity in IBS}

In 1973, Ritchie first reported that IBS patients have pain at lower volumes and pressures when a balloon is inflated in the bowel. ${ }^{31}$ This seminal observation has been replicated by a number of research laboratories, ${ }^{31-36}$ 
Table 3. Studies of Altered GI Motility in IBS

\begin{tabular}{|c|c|c|}
\hline Motility Parameter & Comments & Study \\
\hline \multicolumn{3}{|l|}{ Stomach } \\
\hline & Delayed emptying, greater for solids & $\begin{array}{l}\text { Van Wijk et al.232; Evans et al. }{ }^{233} \text {; Caballero- } \\
\text { Plasencia et al. }{ }^{234}\end{array}$ \\
\hline & Anger inhibits antral motility & Welgan et al. ${ }^{235}$ \\
\hline & $\begin{array}{l}\text { Electrogastrogram abnormal in } 1 / 4 \text { of IBS with comorbid } \\
\text { dyspepsia, but only } 8 \% \text { without dyspepsia }\end{array}$ & Leahy et al. 236 \\
\hline \multicolumn{3}{|l|}{ Small intestine } \\
\hline \multirow[t]{3}{*}{$\begin{array}{l}\text { Discrete clustered } \\
\text { contractions }\end{array}$} & $\begin{array}{l}\text { Increased frequency, duration of DCCs; DCCs associated } \\
\text { with pain }\end{array}$ & $\begin{array}{l}\text { Kumar and Wingate } 237 \text {; Kellow et al. }{ }^{238} \text {; Schmidt } \\
\text { et al. }{ }^{239} \text {; Simren et al. }{ }^{240}\end{array}$ \\
\hline & No increase in DCCs & Gorard et al. ${ }^{241}$ \\
\hline & Increased DCCs following $\mathrm{CRH}$ & Fukudo et al. ${ }^{242}$ \\
\hline $\begin{array}{l}\text { Prolonged propagating } \\
\text { contractions }\end{array}$ & $\begin{array}{l}\text { No increase in frequency, but PPCs associated with pain } \\
\text { in IBS }\end{array}$ & Kellow and Phillips 243 \\
\hline \multirow[t]{2}{*}{ Migrating motor complex } & Increased frequency of MMCs & Kellow and Phillips ${ }^{45}$ \\
\hline & Normal frequency of MMCs & Gorard et al. ${ }^{241}$ \\
\hline \multirow[t]{3}{*}{ Phasic contractions } & Duodenal and jejunal contractions suppressed by stress & Kellow et al. ${ }^{244}$ \\
\hline & $\begin{array}{l}\text { Greater increase in ileum with distention, fatty meal and } \\
\text { CCK }\end{array}$ & Kellow and Phillips 243 \\
\hline & More retrograde duodenal and jejunal contractions & Schmidt et al. ${ }^{239}$; Simren et al. ${ }^{240}$ \\
\hline \multirow[t]{4}{*}{ Small bowel transit } & Delayed in IBS-C; accelerated in IBS-D & Cann et al. ${ }^{245} ;$ Lu et al. ${ }^{246}$ \\
\hline & Accelerated in IBS-D & Vassallo et al. ${ }^{247}$ \\
\hline & $\begin{array}{l}\text { Impaired transit of infused gas resulting in discomfort/ } \\
\text { pain }\end{array}$ & Serra et al. ${ }^{29}$ \\
\hline & IBS patients more likely to perceive occurrence of MMCs & Kellow et al. ${ }^{30}$ \\
\hline \multicolumn{3}{|l|}{ Colon and rectum } \\
\hline \multirow[t]{6}{*}{ Phasic contractions } & $\begin{array}{l}\text { No difference from control at rest, but greater increase } \\
\text { following rectosigmoid distention }\end{array}$ & Whitehead and Drescher 248 \\
\hline & Greater increase after meal & Rogers et al. ${ }^{249}$ \\
\hline & Greater increase with stress & Welgan et al. ${ }^{111}$; Fukudo and Suzuki ${ }^{250}$ \\
\hline & Greater increase with neostigmine & Fukudo and Suzuki250 \\
\hline & $\begin{array}{l}\text { Increased number and amplitude of HAPCs in colon; } \\
\text { increased phasic motility in descending colon and } \\
\text { response to intravenous CKK }\end{array}$ & Ladabaum et al. 251 \\
\hline & Greater increase with $\mathrm{CRH}$ & Fukudo et al.242 \\
\hline Myoelectric activity & $\begin{array}{l}\text { Increased long spike bursts with diarrhea; irregular short } \\
\text { spike bursts with constipation }\end{array}$ & Bueno et al. 252 \\
\hline \multirow[t]{3}{*}{ Compliance and tone } & Normal compliance in IBS & Whitehead et al. ${ }^{248}$ \\
\hline & $\begin{array}{l}\text { Normal fasting and postprandial tone in descending } \\
\text { colon }\end{array}$ & Vassallo et al. 253 \\
\hline & Increased fasting muscle tone in rectum & Whitehead et al. ${ }^{254}$; Blomhoff et al. ${ }^{255}$ \\
\hline \multirow[t]{2}{*}{ Colonic transit } & Delayed in IBS-C; accelerated in IBS-D & Cann et al. 245 \\
\hline & $\begin{array}{l}\text { Whole gut and colonic transit accelerated in IBS-D, but } \\
\text { normal in IBS-C }\end{array}$ & Horikawa et al. 256 \\
\hline
\end{tabular}

$\mathrm{DCC}$, discrete clustered contractions; $\mathrm{CRH}$, corticotropin-releasing hormone; CCK, cholecystokinin; HAPC, high-amplitude propagated contractions; IBS-C, constipation predominant IBS; IBS-D, diarrhea-predominant IBS; MMC, migrating myoelectric complex; PPC, prolonged propagated contractions.

and the threshold to report pain is below the normal range in $50 \%-70 \%$ of IBS patients. Consistent with the concept of enhanced perception of visceral events are observations that IBS patients are more likely than controls to notice intestinal contractions ${ }^{37}$ and gas, ${ }^{29}$ and their pain thresholds are correlated, albeit weakly, with the amount of clinical pain they experience. ${ }^{32,38,39}$

Enhanced perception of visceral events is documented throughout the GI tract, including the esophagus, ${ }^{40}$ stomach, ${ }^{41}$ duodenum, ${ }^{42-44}$ and ileum. ${ }^{45}$ However, IBS patients do not show somatic hypersensitivity to pain ${ }^{42,46,47}$ and may have elevated ${ }^{48,49}$ somatic pain thresholds.
One study ${ }^{32}$ noted that when combining other measures of pain sensitivity, such as the intensity with which the pain sensation is described and the location and size of the somatic referral area, up to $95 \%$ of patients show evidence of visceral hypersensitivity. The investigators concluded that visceral hypersensitivity might be a biological marker for IBS, although this interpretation has been challenged. ${ }^{38}$

\section{Inflammation}

Preliminary evidence for a possible alteration in gut immune function in IBS comes from both unselected 
Table 4. CNS Modulation of Gut Sensations

\begin{tabular}{llc}
\hline \multicolumn{1}{c}{ Central mechanism } & Targets of modulation & Resulting mechanism of sensitization \\
\hline Autonomic nervous system & $\begin{array}{c}\text { Gut effector cells (enterochromaffine cells, immune } \\
\text { cells, smooth muscle cells, ICCs) } \\
\begin{array}{l}\text { Descending bulbospinal pathways } \\
\text { (inhibitory, facilitatory) }\end{array}\end{array}$ & $\begin{array}{c}\text { Modulation of peripheral afferent nerve } \\
\text { terminal excitability } \\
\text { Ascending arousal systems }\end{array}$ \\
\hline
\end{tabular}

ICCs, interstitial cells of Cajal.

and so-called postinfectious IBS (PI-IBS) patients. In unselected patients, increased numbers of mast cells in the muscularis externa of the colon ${ }^{50}$ and the ileal and colonic mucosa ${ }^{51,52}$ have been reported. Increased cellularity of the colonic mucosa and lamina propria has also been described in unselected IBS patients using semiquantitative microscopy. ${ }^{53}$ In patients with intractable IBS, lymphocytic infiltrates of the myenteric plexus were reported, ${ }^{54}$ and most recently, preliminary evidence for increased iNOS (nitric oxide synthetase) expression was described. ${ }^{55}$ For subgroups of IBS, these findings suggest there is an up-regulation of gut immune function. However, methodological deficiencies exist, including the influence of the bowel preparation, the classification of the patients, and the nonquantitative analysis of gut cells. Further studies are needed to explore these intriguing findings.

Further support for a possible role of altered gut immune function in IBS comes from recent studies in PI-IBS patients. ${ }^{56-59}$ A subset of IBS patients associate the development of IBS symptoms with the onset of gastroenteritis. ${ }^{60-62}$ In recent prospective studies, IBS-like symptoms were found in $7 \%-30 \%$ of patients who recovered from a proven bacterial gastroenteritis. ${ }^{59}$ Reported risk factors included: female gender, duration of the acute diarrheal illness, and the presence of significant life stressor occurring around the time of the infection. Patients with PI-IBS were found to have a variety of functional alterations, including changes in gut motility, ${ }^{63,64}$ epithelial function, ${ }^{65,66}$ and an increase in colonic enterochromaffin cells. ${ }^{66} \mathrm{In}$ addition, evidence for increased expression of interleukin $1 \beta$ messenger RNA, increased cellularity of lamina propria, and an increase in $\mathrm{CD}^{+}$lymphocytes were reported from mucosal biopsy specimens. ${ }^{66}$ The correlation of IBS symptoms with these observed changes has not been established. Furthermore, because the majority of patients do not develop postinfectious diarrhea and the prevalence of IBS is not higher in countries with high rates of enteric infections, further studies are required to determine if vulnerability factors (such as altered neuroimmune system responsiveness) play a role in the development of PI-IBS in a subset of patients. In addition, psychological distress seems to be an important cofactor in determining who retains symptoms after an enteric infection. ${ }^{67}$

\section{Autonomic Activity}

Abnormalities in extrinsic autonomic innervation of the viscera occur in approximately one fourth of patients with functional bowel disorders. ${ }^{68,69}$ Aggarwal et al. showed that cardiovagal dysfunction is specifically associated with a constipation-predominant subgroup of patients with IBS, whereas patients with diarrhea-predominant symptoms had evidence of sympathetic adrenergic dysfunction. ${ }^{70}$ The role of autonomic dysfunction in IBS requires further evaluation.

\section{Central Nervous System Modulation}

In general, brain-gut interactions play a prominent role in the modulation of gut function in health and disease..$^{71-74}$ Signals from the brain to the gut assure that digestive function is optimized for the overall state of the organism (e.g., sleep vs. wake, stress vs. relaxation). ${ }^{75}$ Conversely, signals from the gut to the brain play a role primarily in reflex regulation ${ }^{76}$ as well as in modulation of mood states. ${ }^{77}$ In addition, certain vagal afferent pathways can influence pain perception. ${ }^{78}$

The CNS modulates motility, secretion, immune function, and blood flow. ${ }^{79}$ The emotional motor system in the brain ${ }^{80}$ is a revised name for the limbic system and some paralimbic structures (including the medial prefrontal cortex, amygdala, and hypothalamus) communicate emotional changes via the autonomic nervous system to the gut. The CNS is also essential in the perception of events occurring within the gut. This brain-gut bidirectional communication is largely not perceived consciously. In effect, the CNS functions as a "filter" with regard to the perception of peripheral afferent signals, and the threshold for perception can vary depending on the individual's emotional and cognitive state. Most visceral afferent signals reach the brainstem and thalamus, and only a very few are consciously perceived in the cortex. ${ }^{81}$ However, one recent study ${ }^{82}$ suggests that low intensity signals are subliminally registered. 
Modulation of visceral afferent information occurs at multiple levels from the periphery to cortical regions, as shown in Table 4. The activation of these modulatory systems is dependent on peripheral as well as central events, even though the latter seem to be dominant. For example, although acute gut inflammation results in sensitization of peripheral, spinal, and central transmis$\operatorname{sion},{ }^{83}$ it is hypothesized that chronic inflammation may adaptively down-regulate perceptual sensitivity. ${ }^{49,84,85}$ Stress, anxiety, or recall of aversive memories all can enhance perception of painful events, ${ }^{86}$ whereas distraction, hypnosis, and relaxation can decrease perceptual sensitivity. ${ }^{87,88}$ Stress-induced visceral hyperalgesia ${ }^{89}$ may be an important mediator of visceral hypersensitivity in IBS patients. Therapeutic approaches aimed at attenuating stress responsiveness may effectively prevent the development of stress-induced visceral hypersensitivity, as well as attenuate autonomic gut responses to stress. ${ }^{90,91}$

Evidence for the alterations in the way the brain responds to visceral stimuli, and how this response may be altered in IBS patients, comes from recent studies using functional brain imaging techniques. ${ }^{92-96}$ Two of the studies, using distal colonic stimulation, have shown a greater activation in IBS patients of the midcingulate cortex, a brain region concerned with attentional processes and response selection. ${ }^{97,98}$ Modulation of this region by hypnotic suggestion was associated with changes in the subjective unpleasantness of a somatic pain stimulus in another study. ${ }^{88}$ The extent of abnormal visceral afferent processing by the brain in IBS patients needs to be established because they may be plausible mediators of various therapeutic approaches: cognitive therapies are likely mediated via networks involving the lateral prefrontal cortex, which in turn enhance the restraining effect of the medial prefrontal cortex on the emotional motor system. ${ }^{77}$ Hypnosis is likely to modulate attentional mechanisms (including the midcingulate cortex), ${ }^{88,99}$ and relaxation exercises involving deep breathing techniques may alter vagal afferent input to the brain. Centrally targeted medications such as anxiolytics, low dose tricyclic antidepressants (TCAs), NK-1R antagonists, and CRF1R (corticotropin releasing factor 1R) antagonists all involve inhibitory effects on the responsiveness of the emotional motor system and provide options for future therapeutic investigations.

\section{Role of Psychosocial Factors in IBS}

Research on the psychosocial aspects of patients with IBS has yielded 4 general observations. ${ }^{100}$
1. Psychologic stress exacerbates GI symptoms. Although stressful experiences produce GI symptoms in most individuals, patients with IBS are particularly susceptible. ${ }^{10}$ Studies of the effects of stressful life events on IBS patients are shown in Table 5. With one exception, ${ }^{101}$ these studies suggest IBS patients report more lifetime and daily stressful events, ${ }^{10,14,102-107}$ including severe abuse history, ${ }^{108,109}$ than medical comparison groups or healthy controls. Furthermore, in IBS patients, stress is strongly associated with symptom onset ${ }^{105,107,110}$ and symptom severity. ${ }^{109}$ Even though the effects of stress on gut function are universal, patients with IBS seem to have greater reactivity to stress. ${ }^{72,111}$ The identification of specific psychological stressors associated with exacerbation of symptoms may help in planning treatment through psychological or psychopharmacological interventions.

2. Psychological and psychiatric comorbidity is common among patients with IBS. A large proportion of patients with IBS and other functional bowel disorders have concurrent psychological disturbances. As shown in Table 6, when using standardized research interviews, the prevalence of a psychiatric disorder ranges from $40 \%$ to over $90 \%$ among patients with IBS/functional bowel disorders in tertiary care centers. Other psychological features identified to be greater in IBS include personality style, ${ }^{14,106,112}$ psychological distress, ${ }^{18,109,113}$ and altered health beliefs, cognitions, and coping style. ${ }^{114-117}$ As indicated below, these findings are not associated with the disorder per se, but their prevalence is over-represented within the health care-seeking subset of patients.

3. Psychosocial factors affect health status and clinical outcome. Psychological and sociocultural factors, when present in patients with IBS, will also influence the illness experience and treatment outcome. Psychosocial factors that adversely affect health status and clinical outcome include: (1) a history of emotional, sexual, or physical abuse ${ }^{109,118-121}$; (2) stressful life events ${ }^{104,110}$; (3) chronic social stress $^{122}$ or anxiety disorder ${ }^{123,124}$; and (4) maladaptive coping style. ${ }^{119}$ Some of these psychosocial influences may occur early in life. For example, increased attention by family to a child's illness complaints seems to result in delayed symptom reporting, health care seeking, and health care costs. ${ }^{125-129}$ 
Table 5. Effects of Stress on IBS Symptoms

\begin{tabular}{|c|c|c|c|}
\hline Subjects studied & Assessment & Results & Study \\
\hline $\begin{array}{l}102 \text { IBS } \\
158 \text { UC } \\
735 \text { Controls }\end{array}$ & Unvalidated stress interview & More stress in IBS than in IBD or healthy controls & Mendeloff et al. ${ }^{102}$ \\
\hline $\begin{array}{l}20 \text { IBS } \\
20 \text { IBD } \\
20 \text { Appendicitis }\end{array}$ & $\begin{array}{l}\text { Standardized life event } \\
\text { scale }\end{array}$ & $\begin{array}{l}\text { More stressful events reported by IBS patients than } \\
\text { controls }\end{array}$ & Fava and Pavan ${ }^{103}$ \\
\hline $\begin{array}{l}135 \text { IBS } \\
654 \text { Controls }\end{array}$ & $\begin{array}{l}\text { Self-report that stress } \\
\text { affects bowel symptoms }\end{array}$ & $\begin{array}{l}72.6 \% \text { of IBS and } 54.4 \% \text { of controls reported stress led } \\
\text { to change in stool pattern } \\
84.4 \% \text { of IBS and } 67.6 \% \text { of controls reported stress led } \\
\text { to abdominal pain }\end{array}$ & Drossman et al. ${ }^{10}$ \\
\hline $\begin{array}{l}36 \text { IBS } \\
12 \text { Dyspepsia } \\
16 \text { Organic GI }\end{array}$ & $\begin{array}{l}\text { Bedford College life events } \\
\text { and difficulties interview }\end{array}$ & $\begin{array}{l}\text { No relationship between stress and functional bowel } \\
\text { disorder }\end{array}$ & Ford et al. ${ }^{101}$ \\
\hline $\begin{array}{l}72 \text { IBS patients } \\
82 \text { IBS nonconsulters } \\
84 \text { Controls }\end{array}$ & $\begin{array}{l}\text { Standardized life event } \\
\text { scale }\end{array}$ & $\begin{array}{l}\text { IBS patients reported: } \\
\text { fewer negative stressful events and perceive them as } \\
\text { less severe } \\
\text { fewer positive life events } \\
\text { IBS nonconsulters reported more negative life events } \\
\text { than controls }\end{array}$ & Drossman et al. ${ }^{14}$ \\
\hline $\begin{array}{l}79 \text { Functional } \\
56 \text { Organic } \\
135 \text { Control }\end{array}$ & $\begin{array}{l}\text { Psychiatric interview based } \\
\text { on the life events and } \\
\text { difficulty schedule }\end{array}$ & $\begin{array}{l}60 \%-66 \% \text { had experienced severe life events preceding } \\
\text { onset of IBS vs. } 25 \% \text { of controls for an arbitrary } \\
\text { time }\end{array}$ & Creed et al. 110 \\
\hline $\begin{array}{l}206 \text { Female Gl clinic } \\
\text { patients }\end{array}$ & $\begin{array}{l}\text { Questionnaire used to } \\
\text { detect physical and } \\
\text { sexual abuse }\end{array}$ & $\begin{array}{c}\text { Patients more likely to report physical or sexual abuse } \\
\text { compared with patients with organic Gl disorders }\end{array}$ & Drossman et al. ${ }^{108}$ \\
\hline $\begin{array}{l}40 \text { IBS } \\
32 \text { Peptic ulcer }\end{array}$ & Psychosocial assessment & $\begin{array}{l}\text { IBS patients: } \\
\text { reported greater negative life events } \\
\text { scored higher for neuroticism and extroversion } \\
\text { not different from ulcer patients for psychiatric } \\
\text { diagnoses }\end{array}$ & Dinan et al. ${ }^{106}$ \\
\hline $\begin{array}{l}39 \text { IBS } \\
108 \text { FBD } \\
232 \text { Controls }\end{array}$ & $\begin{array}{l}\text { Life event questionnaire } \\
\text { given every } 3 \text { months for } \\
1 \text { year ( } 5 \text { times) }\end{array}$ & $\begin{array}{l}\text { Stressful events more common in IBS } \\
\text { Stress correlated with: } \\
\text { number of bowel symptoms } \\
\text { disability days } \\
\text { physician visits } \\
\text { Patients and nonpatients with IBS show greater } \\
\text { reactivity to stress than people without IBS }\end{array}$ & Whitehead et al. ${ }^{104}$ \\
\hline $\begin{array}{l}239 \text { Women in Gl } \\
\text { clinic with 1-year } \\
\text { follow-up }\end{array}$ & $\begin{array}{l}\text { Standardized abuse history } \\
\text { interview and } \\
\text { psychosocial/outcome } \\
\text { questionnaires }\end{array}$ & $\begin{array}{l}\text { Abuse history was associated with poorer health status } \\
\text { and outcome with regard to: } \\
\text { pain scores } \\
\text { bed disability days } \\
\text { psychological distress } \\
\text { daily function } \\
\text { health care visits } \\
\text { lifetime surgeries } \\
\text { Severe abuse history more prevalent in functional vs. } \\
\text { organic disorders }\end{array}$ & Drossman et al. ${ }^{109}$ \\
\hline $\begin{array}{l}26 \text { IBS patients } \\
23 \text { IBS nonpatients } \\
26 \text { Controls }\end{array}$ & $\begin{array}{l}\text { Evaluated relationship } \\
\text { between daily stress } \\
\text { using and Gl symptoms } \\
\text { using daily diaries and } \\
\text { LES }\end{array}$ & $\begin{array}{l}\text { IBS and IBS nonpatients vs. controls } \\
\text { higher mean GI symptoms and stress } \\
\text { no difference in LES scores } \\
\text { Within group both IBS and IBS nonpatients: significantly } \\
\text { positive relationship between daily stress and daily } \\
\text { symptoms }\end{array}$ & Levy et al. ${ }^{107}$ \\
\hline $\begin{array}{l}154 \text { Children with RAP } \\
109 \text { Well children }\end{array}$ & $\begin{array}{l}\text { Consecutive daily telephone } \\
\text { interviews to assess daily } \\
\text { stressors and symptoms }\end{array}$ & $\begin{array}{l}\text { More frequent daily stressors than well children } \\
\text { Association between daily stressors and symptoms was } \\
\text { stronger for patients with RAP than well children }\end{array}$ & Walker et al. ${ }^{105}$ \\
\hline
\end{tabular}

LES, life event survey; RAP, recurrent abdominal pain. 
Table 6. Prevalence of Psychiatric Disorder in Functional Bowel Disorder/IBS Using Standardized Research Psychiatric Interviews

\begin{tabular}{|c|c|c|c|c|c|}
\hline Number of subjects & $\begin{array}{l}\text { Instrument for } \\
\text { psychiatric } \\
\text { disorder }\end{array}$ & $\begin{array}{c}\text { Functional bowel } \\
\text { disorders }\end{array}$ & $\begin{array}{c}\text { Organic } \\
\text { gastrointestinal } \\
\text { disorder }\end{array}$ & $\begin{array}{l}\text { Healthy } \\
\text { controls }\end{array}$ & Study \\
\hline 32 (FBD) & CIS & $53 \%$ & $20 \%$ & - & McDonald and Bouchier257 \\
\hline 79 (FBD) & PSE & $42 \%$ & $18 \%$ & - & Craig and Brown 258 \\
\hline 44 (IBS) & PSE & $42 \%$ & $6 \%$ & $8 \%$ & Ford et al. 101 \\
\hline 37 (FBD) & $\mathrm{CIS}$ & $57 \%$ & $6 \%$ & - & Colgan et al. ${ }^{259}$ \\
\hline 48 (IBS) & CIS & $48 \%$ & - & - & Corney and Stanton 260 \\
\hline 44 (IBS) & DIS & $61 \%$ & - & $14 \%$ & Toner et al. ${ }^{261}$ \\
\hline 68 (IBS) & DIS & $56 \%$ & $25 \%$ & $18 \%$ & Blanchard et al.262 \\
\hline 71 (IBS) & DIS & $94 \%$ & $65 \%$ & - & Walker et al. ${ }^{263}$ \\
\hline 50 (IBS) & SCID & $54 \%$ & - & - & Irwin et al. 264 \\
\hline
\end{tabular}

FBD, functional bowel disorder (e.g., consecutive nonorganic gastrointestinal disorders in the clinic); CIS, clinical interview schedule; PSE, present state examination; DIS, diagnostic interview schedule for diagnostic statistical manual (DSM-IIIR and DSM-IV); SCID, structured clinical interview for DSM-IIIR and DSM-IV.

4. Psychosocial factors influence which patients consult physicians. This tends to overestimate the true prevalence of psychosocial disturbance when evaluating patients in referral clinical settings. In fact, persons with IBS who do not see physicians are psychologically similar to subjects without bowel complaints. ${ }^{14,18,130}$

\section{IBS Can Lead to Impaired HRQL}

HRQL addresses the psychological and social consequences of having IBS. It incorporates the patient's perceptions, illness experience, and functional status. ${ }^{131}$ Several self-administered questionnaires to study HRQL now exist for GI disorders ${ }^{132}$ and IBS. ${ }^{133}$ To date, 2 IBS-specific instruments have been shown to be responsive to change. ${ }^{134,135}$

The data show that patients with functional GI disorders have poorer functional status (Sickness Impact Profile) than those with organic GI diagnoses. ${ }^{109}$ In addition, patients with IBS have significantly poorer HRQL (SF-36) than the general population or of patients with gastroesophageal reflux disease, and have selected impairments in HRQL relative to patients with diabetes and end-stage renal disease. ${ }^{136}$ However, the degree of impairment also relates to the population being studied: nonpatients with IBS have HRQL scores (SF-36) that are intermediate between referred IBS patients (who were similar to patients with congestive heart failure) and normal controls. ${ }^{137}$ When using IBS-specific questionnaires, patients show the lowest scores related to interference with activity, food avoidance, and health worry concern (IBS quality of life). ${ }^{138}$ Moreover, quality of life improves in relation to changes in pain severity and daily function after psychological or antidepressant treatment. ${ }^{134}$ When compared with patients having other GI conditions, physical, emotional, and social role functions and energy (IBS quality of life) were poorer. ${ }^{139}$

Figure 1 provides a conceptual model on the role of psychosocial factors on illness and outcome in IBS. Early life factors influence later psychosocial experiences, physiologic functioning, and susceptibility to developing IBS. Therefore, a psychosocial stressor, interpreted from previous experiences, may produce symptoms primarily through changes in intestinal function, central amplification of normal gut signals, or a combination of these factors. The combined and integrated effects of altered physiology and the person's psychosocial status via the brain-gut axis affects how the symptom is experienced, the individual's illness behavior, and ultimately the outcome. Furthermore, the clinical outcome will, in turn, affect the severity of the disorder. Therefore, while psychosocial factors are not etiologic to IBS, they are rele-

IBS - Conceptual Model

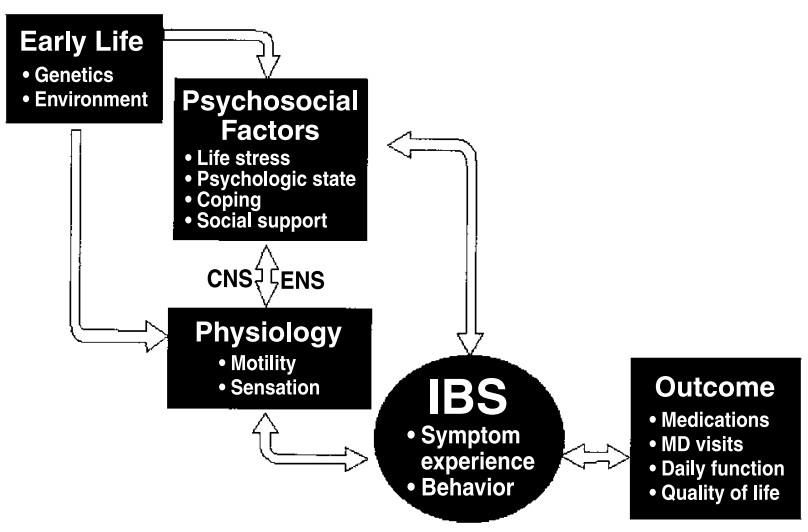

Figure 1. A conceptual model depicting the relationship between early life, psychosocial factors, physiology, symptom experience, and behavior and outcome. See text for details. 


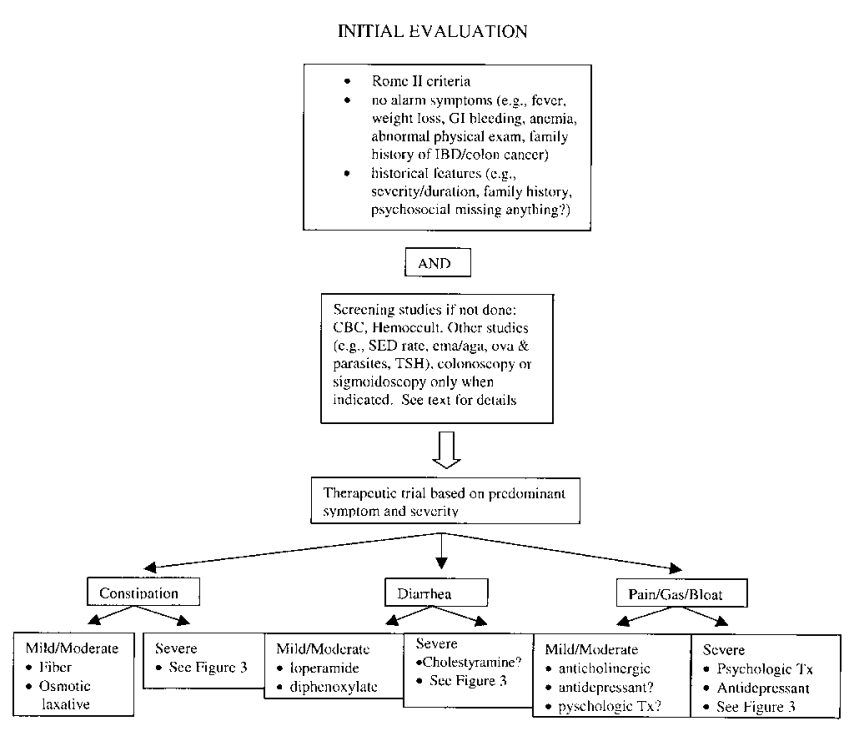

Figure 2. Initial evaluation by the gastroenterologist for patients with IBS.

vant to understanding the patient's adjustment to IBS, the clinical outcome, and the plan of treatment.

\section{Diagnosis}

\section{Symptom-Based Criteria}

A diagnosis is based on identifying positive symptoms (e.g., Rome criteria) consistent with the condition (Table 1), and excluding, in a cost-effective manner, other conditions with similar clinical presentations, which may include organic or other functional (e.g., functional diarrhea or bloating, pelvic floor disorders, or slow transit constipation with associated abdominal discomfort relieved with defecation) disorders., 3,140 Any needed tests, as suggested by "alarm features," should be discussed with the patient and set up at the first encounter. When "alarm features" such as weight loss, refractory diarrhea, and family history of colon cancer are excluded, the specificity of the symptom-based Rome I criteria for IBS exceeds $98 \%$ and hence, the risk of missing organic disease is low. ${ }^{141}$

\section{Evaluation}

A physical examination should be performed on the first visit and on subsequent visits as needed. This is done to exclude findings not consistent with IBS (e.g., enlarged liver, abdominal mass, signs of bowel obstruction) and to meet the patient's expectations of a thorough evaluation. A pelvic examination is often indicated for lower abdominal/pelvic symptoms and/or if there is a change in menstrual pattern. A rectal examination, particularly for patients reporting symptoms of incontinence or dyschezia, can help to identify a lax sphincter or paradoxical pelvic floor muscle contraction. This may require anorectal testing of pelvic floor muscle function.

Two algorithms applicable to the evaluation of patients with IBS seen in primary care settings have recently been presented. ${ }^{142}$ Figures 2 and 3 , as summarized below, provide an algorithm for patients presenting to gastroenterologists.

In general, if Rome criteria are fulfilled, "alarm signs" or "red flags" are not present, and screening studies from the referring physician are negative, further testing is not needed. Screening studies are recommended when certain historical information is present ${ }^{143}$ : (1) short symptom duration or worsening severity and trajectory of symptoms, (2) demographic features (e.g., onset in an older patient), (3) family history (e.g., colon cancer or inflammatory bowel disease), and (4) no concurrent psychosocial difficulties or symptom behaviors (particularly the absence of comorbid psychosocial features or health care seeking). We recommend a complete blood count and a stool hemoccult for screening purposes. A sedimentation rate (particularly in a younger patient), serum chemistries, thyroid-stimulating hormone (TSH), and stool for ova and parasites can be ordered based on symptom pattern, geographic area, and relevant clinical features (e.g., predominant diarrhea, areas of endemic infection). However, studies do not generally support a role for these tests without supportive clinical features. ${ }^{144} \mathrm{~A}$ colonoscopy is recommended for patients over age 50 (due to higher pretest probability of colon cancer), but in younger patients, performing a colonoscopy or sigmoidoscopy is determined by clinical features suggestive of disease (e.g, if there is significant diarrhea) and may not be indicated. There has been growing interest in the use of antiendomysial (ema) and antigliadin (aga) antibodies to diagnose celiac sprue. ${ }^{145-147}$ However, such testing

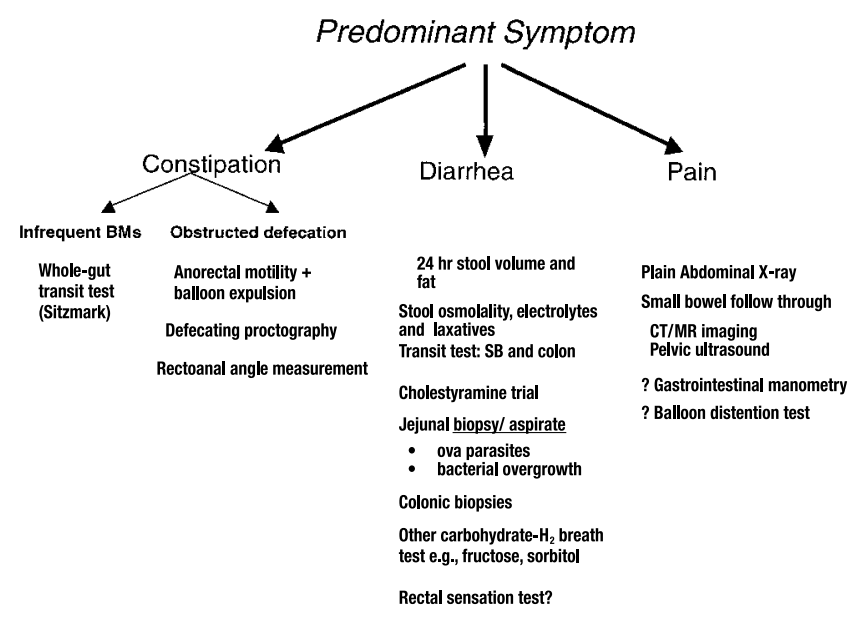

Figure 3. Diagnostic evaluation based on symptom subtype after initial treatments are insufficient to control patient's symptoms. 
must be put into a clinical perspective as determined by presence of symptom pattern, ethnicity, and other clinical features suggestive of the disease. ${ }^{143}$

In many cases, the therapeutic trial can be undertaken before further diagnostic studies are done and will depend on the symptom subtype and its severity (Figure 2): for constipation, fiber, or an osmotic laxative; for diarrhea, loperamide, or diphenoxylate-atropine and possibly cholestyramine; and for pain/gas/bloating, an anticholinergic, or, if more severe, antidepressant or psychologic treatment may be considered. It needs to be emphasized that patients presenting with typical symptoms and no "alarm" signs are rarely found to have another diagnosis, ${ }^{144,148}$ supporting the benefit of ongoing care and symptomatic management rather than continued diagnostic evaluation.

If initial treatment fails, or certain clinical features emerge requiring further evaluation, we recommend the algorithm indicated in Figure 3. Many of these studies are performed by gastroenterologists in specialty centers.

In patients with infrequent bowel movements, whole gut transit study by Sitzmark technique or a plain radiography (to evaluate for obstructive signs or fecal retention) is indicated. When symptoms of dyschezia or incomplete evacuation are prominent, suggesting obstruction to defecation, or when the physical examination discloses poor pelvic floor relaxation with straining, further anorectal testing is indicated. This includes anorectal motility testing with balloon expulsion (to evaluate for pelvic floor dyssynergia) or defecography (to evaluate for enterocele or rectocele).

If diarrhea is persistent, other tests to consider include: 24 -hour stool volume and fat; if increased $(>400 \mathrm{~mL} /$ day), electrolytes and laxative screen; and small bowel biopsy for giardia lamblia or sprue and colonic biopsy for microscopic colitis. On occasion, transit tests of the small bowel and colon can help evaluate the severity of the motility component of the diarrhea. A therapeutic trial of cholestyramine may also be considered, particularly if symptoms developed or worsened after a cholecystectomy. A jejunal biopsy and aspirate can be done to obtain samples to assess malabsorption (e.g., sprue), or to obtain an aspirate for giardia or for bacterial overgrowth. Colonic biopsies can be considered to evaluate for collagenous or lymphocytic colitis, although the findings may not lead to instituting more effective treatments. Finally, when postprandial symptoms of bloating and gaseousness accompany the diarrhea, a breath $\mathrm{H}_{2}$ study to exclude bacterial overgrowth can be considered. ${ }^{149}$

The persistence of pain-predominant symptoms or severe bloating usually requires plain abdominal radiog-
Table 7. Spectrum of Clinical Features Among Patients With IBS

\begin{tabular}{lccc}
\hline \multicolumn{1}{c}{ Clinical feature } & Mild & Moderate & Severe \\
\hline Estimated prevalence & $70 \%$ & $25 \%$ & $5 \%$ \\
Practice type & Primary & Specialty & Referral \\
Correlation with gut & & & \\
$\quad$ physiology & +++ & ++ & + \\
Symptoms constant & 0 & + & +++ \\
Psychosocial difficulties & 0 & + & +++ \\
Health care use & + & ++ & +++ \\
IIIness behavior & 0 & + & +++ \\
Psychiatric diagnoses & 0 & + & +++ \\
\hline
\end{tabular}

0 , Generally absent; + , mild; ++ , moderate; +++ , marked. Data from Drossman. ${ }^{265}$

raphy during an acute episode to exclude bowel obstruction, an increased gastric air bubble from aerophagia, and/or other abdominal pathology. If negative, additional imaging studies (e.g., small bowel radiography, computerized tomography scan, pelvic ultrasonography) may be recommended, particularly when there are other symptoms or signs present (e.g., vomiting, weight loss, abdominal mass, irregular menses, abnormal chemistries). A balloon distention test may confirm rectal or colonic visceral hypersensitivity, although this test is usually done for investigative purposes.

\section{Treatment}

The treatment strategy is based on the nature and severity of the symptoms, the correlation of IBS symptoms with food intake and/or defecation, the degree of functional impairment, and the presence of psychosocial difficulties and psychiatric comorbidity affecting the course of the illness. Table 7 provides a practical framework, supported by recent empiric evidence ${ }^{150}$ for differentiating patients into subgroups of severity based primarily on patient pain reports and behaviors. ${ }^{22,151,152}$ In general, milder symptoms relate primarily to visceral hyperactivity and/or hypersensitivity and are commonly treated symptomatically with pharmacological agents directed at the gut, whereas more severe symptoms are associated with greater levels of psychosocial difficulties and illness behaviors and often require psychological/ behavioral and antidepressant medications.

The most frequently seen group of IBS patients have mild symptoms. They are usually cared for in primary care practices, usually maintain normal daily activities, have little or no psychosocial difficulties (although they may experience symptom exacerbations with stress), and are not high health care users. Treatment involves education, reassurance, and dietary/lifestyle changes. A smaller proportion of patients have moderate symptoms 
that are usually intermittent, although at times disabling. Symptoms may be associated with considerable symptom-related distress, and historical symptoms are associated with greater physiological gut reactivity (e.g., worse with eating, relieved by defecation). Treatments involve gut-acting pharmacological agents (e.g., anticholinergics, antidiarrheals, newer GI treatments, etc.), and if more persistent, possibly low-dose TCAs and/or psychological treatments. Finally, only a very small proportion of patients with IBS have severe and sometimes refractory symptoms. These symptoms predominate among patients seen in referral centers; these patients frequently have more severe, often constant pain symptoms, psychiatric comorbidity (e.g., depression, anxiety disorders), and psychosocial difficulties (history of sexual/ physical abuse, poor coping) associated with high health care use rates. These patients require antidepressant medication and possibly mental health or pain center referral, along with an ongoing relationship with the primary care physician to provide psychosocial support through brief, regular visits. ${ }^{153}$

\section{General Treatment Approach}

The therapeutic relationship. An effective physician-patient relationship is the cornerstone of effective treatment. Here, the physician must: (1) listen actively to determine the patient's understanding of the illness and his or her concerns, (2) provide a thorough explanation of the disorder, (3) identify and respond to the patient's concerns and expectations, (4) set realistic and consistent limits, (5) involve the patient in the treatment, and (6) establish a long-term relationship with a primary care provider. ${ }^{153,154}$ This type of approach is associated with a reduction in health care visits ${ }^{155}$ and improved patient satisfaction. Patients who do not feel properly informed have more health care visits. ${ }^{156}$ Furthermore, when diagnostic and prognostic information is provided, there is also a reduction in symptoms. ${ }^{157}$

As with any chronic illness, it helps to determine the immediate reasons for the patient's visit. These may include: (1) everyday environmental stressors (e.g., difficulty meeting deadlines, financial or relationship problems, daily "hassles"), (2) new exacerbating factors (e.g., dietary change, concurrent medical disorder, side effects of new medication), (3) personal concern about a serious disease (e.g., recent family death), (4) psychiatric comorbidity (e.g., depression, anxiety), (5) major life events or difficulty adjusting to them (e.g., family death, abuse history), (6) impairment in daily function (e.g., recent inability to work or socialize) or (7) a "hidden agenda" (e.g., narcotic or laxative abuse, pending disability or litigation).
Education and reassurance. Education involves an iterative process in which the physician assesses the patient's level of knowledge about the disorder and provides information, verbally or in print, to enhance the patient's understanding. Patients frequently want to understand the basis for their symptoms, and, at times, seek validation that their symptoms are "real." In practice, useful statements include: "You have a common disorder where the intestine overreacts to a variety of stimuli such as food, hormonal changes, medication, and stress. These stimuli can produce spasm or stretching of the gut, enhanced sensitivity of nerves, or both. This is experienced as pain, diarrhea, constipation, bloating, or any combination anywhere in the abdomen." or "IBS is a disorder where communication between the brain and gut is not in order, so bowel disturbance may trigger symptoms of anxiety or distress, which in turn, makes your symptoms worse. We need to understand both your physical symptoms and the associated emotional distress related to it."

Reassurance should follow after the physician elicits the patient's worries and concerns, and after an adequate and generally conservative diagnostic evaluation. If reassurance is communicated in a perfunctory manner before evaluation, the patient will reject it.

Dietary modification. Although many patients may attribute their symptoms to specific food substances, the type of food does not generally contribute to symptoms. Patients are more likely to experience symptoms as a generalized effect of eating, and at times may even become conditioned to reduce eating to avoid postprandial discomfort. However, certain dietary substances may aggravate symptoms in some individuals. This might include fatty foods, beans, and gas-producing foods, alcohol, caffeine, lactose in lactose-deficient individuals, and, in some cases, excess fiber. Care should be taken to avoid an unnecessarily restrictive diet.

Although fiber has an established role in treating constipation, its value for IBS for the relief of diarrhea is controversial and not helpful for pain. In 2 randomized crossover studies of IBS patients, ${ }^{158,159}$ the groups receiving increased fiber ( $15 \mathrm{~g}$ bran and $20 \mathrm{~g}$ corn fiber, respectively) and the control groups had similar degrees of symptomatic improvement.

Symptom monitoring. It helps to have the patient use a diary to monitor symptoms for 2-3 weeks to assess the time and severity of symptoms, the presence of possible aggravating factors, and the emotional and cognitive impact of the symptoms on the individual. ${ }^{153,160}$ The diary may identify dietary indiscretions or specific stressors not previously considered, and may also give the 
patient a sense of participation in the planning of care. The physician can then review and consider diet, lifestyle, or behavioral modifications with the patient. In addition, identification of maladaptive coping styles (e.g., "catastrophizing") ${ }^{119}$ may lead to referral for psychological treatment.

\section{Pharmacotherapy Targeted at Specific Symptoms}

For pain and bloating, antispasmodic (anticholinergic) medication, particularly when symptoms are exacerbated by meals, should be considered. Meta-analyses of available studies suggest that some of these agents may be effective, although the trial methodology was inadequate by modern standards. ${ }^{161}$ In one meta-analysis of smooth muscle relaxants in IBS, ${ }^{162} 5$ drugs showed efficacy over placebo: (1) cimetropium bromide (an antimuscarinic compound), (2) pinaverium bromide and (3) octylonium bromide (quaternary ammonium derivatives with calcium-antagonist properties), (4) trimebutine (a peripheral opiate antagonist), and (5) mebeverine (a derivative of beta-phenyl-ethylamine that has antimuscarinic cholinergic activity). None of these drugs underwent extensive trials in North America or received approval from the Food and Drug Administration (FDA). Notably, the commonly prescribed dicyclomine and hyosyamine were not effective in the meta-analysis. Other meta-analyses have been published with similar conclusions. ${ }^{163-165}$ Eight trials with peppermint oil for IBS, including a meta-analysis of 5 placebo-controlled, doubleblind trials, have not established a role for this treatment in IBS. ${ }^{166}$ There are also meta-analyses on the effect of tricyclic antidepressants, which will be reviewed later.

In clinical practice, antispasmodics and anticholinergic agents are best used on an as-needed basis up to 3 times per day for acute attacks of pain or before meals when postprandial symptoms are present. Agents such as dicyclomine or mebeverine seem to retain efficacy when used on an as-needed basis, but become less effective with chronic use. Low-dose TCAs may be considered when the pain is more constant and/or disabling.

For constipation, increased dietary fiber $(25 \mathrm{~g} /$ day $)$ is recommended for simple constipation, although its effectiveness, based on several studies, in reducing pain in constipation-predominant IBS is mixed (see dietary modification section). If fiber is not helpful, osmotic laxatives such as milk of magnesia, sorbitol, or polyethylene glycol may be used. For diarrhea, loperamide (2-4 mg up to 4 times daily) or diphenoxylate $(2.5 \mathrm{mg}$ and $.025 \mathrm{mg}$ atropine up to 3-4 times a day) can reduce loose stools, urgency, and fecal soiling, ${ }^{167}$ and in low doses, does not seem to affect the CNS. Cholestyramine may be consid- ered for a subgroup of patients with cholecystectomy or bile acid malabsorption. ${ }^{65}$

\section{Investigational Compounds}

A novel approach to the treatment of diarrhea and pain/discomfort of IBS is based on antagonism of the 5- $\mathrm{HT}_{3}$ receptors. 5- $\mathrm{HT}_{3}$ receptors are extensively distributed on enteric motor neurons, on peripheral terminals of visceral afferent nerves, and on central locations such as the vomiting center. Antagonism of these receptors reduces visceral pain, colonic transit, and small intestinal secretion. ${ }^{168}$ Alosetron hydrochloride, a selective $5-\mathrm{HT}_{3}$ antagonist, is effective in relieving pain and normalizing bowel frequency, and reducing urgency in diarrhea-predominant female patients with IBS (effect size $12 \%$ 15\%). ${ }^{169}$ It was more effective than placebo in inducing adequate relief of pain and discomfort and improved bowel frequency, consistency, and urgency ${ }^{170-172}$ in women with diarrhea-predominant IBS. The most common adverse event was constipation, affecting $28 \%$ of patients in clinical trials; only $10 \%$ withdrew from these studies for this symptom. A significant adverse event with an unclear relationship to alosetron is acute ischemic colitis, estimated to occur in $0.1 \%-1 \%$ (risk factors were not identified). The drug was withdrawn from the market in November 2000 because of these side effects, but after further evaluation was reapproved by the FDA in the spring of 2002 under restrictive guidelines to be developed for its use.

Another $5-\mathrm{HT}_{3}$ antagonist, cilansetron, has demonstrated similar efficacy to that of alosetron in 2 phase II trials $^{173}$ and was effective in male patients (possibly because of a larger number of male patients studied). This drug is currently in phase III trials.

For constipation, new partial or full $5-\mathrm{HT}_{4}$ agonists seem promising in the treatment of constipation or constipation-predominant IBS. The partial agonist, tegaserod, is an aminoguanidine indole, which was shown to result in global relief of IBS symptoms and constipation in females with constipation-predominant IBS. ${ }^{174}$ The effective dose of tegaserod is $12 \mathrm{mg}$ per day in 2 divided doses ( $6 \mathrm{mg}$ twice daily). Pooled analysis of the trials to date suggests that the drug is significantly effective, with approximately a $10 \%$ advantage over placebo in the intent to treat population and up to a $14 \%$ advantage over placebo in females and those with documented constipation during the baseline run-in period. Tegaserod appears safe, with no serious adverse events reported in the clinical trials program or in open evaluation for over 6 months. An effect of tegaserod on the delayed rectifier potassium current that rarely leads to cardiac dysrhythmias has been carefully excluded; this appears to 
differentiate the drug from other $5-\mathrm{HT}_{4}$ agonists such as the substituted benzamide, cisapride. The drug was approved by the FDA in July 2002 for females with constipation-predominant IBS symptoms.

The full 5- $\mathrm{HT}_{4}$ agonist, prucalopride, is a benzofuran that induces strong contractions in the proximal colon in vivo in $\operatorname{dogs}{ }^{175}$ and accelerates colonic transit in healthy participants ${ }^{176,177}$ and in patients with functional constipation. ${ }^{74}$ The drug induced a significant increase in the number of spontaneous and complete bowel movements in 2 trials of patients with functional constipation. ${ }^{178,179}$ The effects of prucalopride on abdominal pain have not been thoroughly assessed. Clinical trials have been discontinued because of carcinogenicity in animals.

Other new approaches being explored in phase II studies include: newer type 3 antimuscarinic agents, NK1 and NK3 receptor antagonists, cholecystokinin antagonists, the alpha $_{2}$ adrenergic agonists, clonidine, ${ }^{180}$ a $5-\mathrm{HT}_{1}$ agonist (buspirone), ${ }^{181}$ and a selective serotonin reuptake inhibitor (SSRI) (citalopram). ${ }^{182,183}$ Recommendations on the use of these newer receptor-active agents with regard to being first- or second-line treatments need to be determined based on issues of efficacy, safety, and cost.

\section{Complementary/Alternative Therapies in IBS}

Several reports indicate that the public holds some skepticism toward conventional medicine and are using complementary or alternative medicine therapies more frequently in IBS than with "organic" diseases. ${ }^{184-187}$ However, the efficacy of alternative therapies has not been established in controlled trials. ${ }^{188}$ One exception is a placebo-controlled 16-week trial of Chinese herbal medicines that showed improved bowel symptom scores, global symptoms, and reduced IBS-related interference with life relative to placebo. ${ }^{189}$ Notably, patients receiving individualized Chinese herbal medicine continued to report benefit beyond the actual treatment period. ${ }^{189}$ Many herbs were used, so it is not possible to make specific recommendations.

\section{Psychological Treatment}

Psychological treatment can be considered when IBS symptoms are moderate to severe, when patients have failed to respond to medical treatments, or when there is evidence that stress or psychological factors are contributing to GI symptom exacerbations. The patient's understanding of the rationale for psychological treatment and their motivation to undertake such treatment is critical to a successful outcome. Therefore, the physician has an important role in clearly communicating why referral for psychological treatment is recommended. If this is not done properly, patients may not accept the referral and may even feel abandoned by their physicians. Table 8 indicates that psychological treatments are frequently helpful both at reducing bowel symptoms and improving psychological symptoms.

Psychological treatment trials have methodological limitations because of the inability to blind patients or the investigators as to treatment assignment, and the difficulty of coming up with a placebo treatment that is credible, but also not effective, to patients. There are 14 randomized controlled trials (Table 8), but only 5 included placebo arms; 2 of these placebo-controlled trials were positive, ${ }^{190-192} 1$ showed a trend for greater bowel symptom reduction in the active treatment group, ${ }^{193}$ and 2 showed equivalence between active and placebo arms. ${ }^{194-195}$ Many trials have compared the active psychological intervention to continuation of standard medical therapy or merely to symptom monitoring while waiting to start therapy. However, it is probable that both these control groups are associated with a negative expectancy. Patients are only referred to these trials if they have failed medical therapy, and they are not expected to improve while they are waiting to be treated. Thus, despite a number of positive trials, there is room for doubt.

Currently, no studies indicate that one psychological intervention technique is superior to another. The symptoms associated with a favorable response are abdominal pain, diarrhea, and psychological distress. ${ }^{196}$ Predictors of a positive response to psychological treatment ${ }^{124,196}$ are: (1) awareness that stress exacerbates their bowel symptoms, (2) at least mild anxiety or depression, (3) the predominant bowel symptom is abdominal pain or diarrhea and not constipation, (4) the abdominal pain waxes and wanes (rather than being constant) in response to eating, defecation, or stress, and (5) the symptoms are of relatively short duration. Also, it has been proposed that patients who exhibit maladaptive coping styles or cognitions (e.g., "catastrophizing") relating to their symptoms, or perceive an inability to decrease them, may be particularly responsive to cognitivebehavioral treatment. ${ }^{119,197}$

Psychological treatment is initially expensive because it requires multiple, long sessions. However, its benefits persist or even increase over time, ${ }^{196}$ and in the long run there may be a net reduction in clinic visits and health care costs, ${ }^{198}$ which offsets the initial cost of psychological treatment.

\section{Centrally Targeted (Psychotropic) Medications}

Antidepressants and anxiolytic agents are commonly prescribed by medical physicians, whereas anti- 
Table 8. Randomized Controlled Studies of Psychological Treatments With at Least 20 Subjects and Follow-up at Least 3 Months

\begin{tabular}{|c|c|c|c|}
\hline $\mathrm{N}$ & Type of treatment & Comments & Study \\
\hline \multicolumn{4}{|c|}{ Interpersonal psychotherapy } \\
\hline $\mathrm{n}=101$ & Psychodynamic therapy vs. SMT & $\begin{array}{l}\text { Greater improvement in pain and bowel habits at } \\
\text { EOT and } 15 \text { mo FU }\end{array}$ & Svedlund et al. 266 \\
\hline$n=102$ & Interpersonal therapy vs. SMT & $\begin{array}{l}\text { Greater improvement in pain, bowel habits, } \\
\text { psychological symptoms at EOT and } 12 \text { mo FU }\end{array}$ & Guthrie et al.196 \\
\hline$n=257$ & $\begin{array}{l}\text { Interpersonal therapy vs. SSRI } \\
\text { vs. SMT }\end{array}$ & $\begin{array}{l}\text { No differences in psychological status or bowel } \\
\text { symptoms at EOT or } 12 \mathrm{mo} \mathrm{FU}\end{array}$ & Creed et al. 267 \\
\hline \multicolumn{4}{|c|}{ Cognitive behavior therapy } \\
\hline$n=24$ & $\begin{array}{l}\text { Multicomponent behavior therapy } \\
\text { vs. SMT }\end{array}$ & $\begin{array}{l}\text { Greater reductions in psychological, but no } \\
\text { difference in bowel symptoms }\end{array}$ & Bennett and Wilkinson268 \\
\hline$n=45$ & $\begin{array}{l}\text { Summary of } 5 \text { small-scale } \\
\text { studies of a multicomponent } \\
\text { self-regulatory treatment }\end{array}$ & $\begin{array}{l}58 \% \text { had primary Gl symptoms reduced by at least } \\
50 \% \text {; trait anxiety had noticeable clinical utility } \\
\text { as an individual predictor of outcome }\end{array}$ & Blanchard et al.124 \\
\hline$n=120$ & $\begin{array}{l}\text { Multicomponent behavior therapy } \\
\text { vs. placebo vs. SMT }\end{array}$ & $\begin{array}{l}\text { No difference between active treatment and } \\
\text { placebo; both superior to SMT }\end{array}$ & Blanchard et al. ${ }^{194}$ \\
\hline$n=20$ & Individual CBT vs. SMT & Reduced bowel symptoms at EOT and 3 mo FU & Greene and Blanchard269 \\
\hline$n=34$ & $\begin{array}{l}\text { Individual CBT vs. self-help } \\
\text { support group vs. SMT }\end{array}$ & $\begin{array}{l}\text { Bowel symptoms and psychological symptoms } \\
\text { reduced relative to placebo at EOT and } 3 \text { mo FU }\end{array}$ & Payne and Blanchard ${ }^{190}$ \\
\hline$n=45$ & Group CBT vs. SMT & $\begin{array}{l}\text { Decreased bowel symptoms and increased ability } \\
\text { to cope at EOT and } 2 \text { year FU }\end{array}$ & Van Dulmen et al. 270 \\
\hline$n=101$ & Group CBT vs. education vs. SMT & $\begin{array}{l}\text { CBT showed greater reductions in psychological } \\
\text { distress and tended to show greater reduction } \\
\text { in bowel symptoms }\end{array}$ & Toner et al. ${ }^{193}$ \\
\hline$n=24$ & $\begin{array}{l}\text { Multicomponent behavior therapy } \\
\text { vs. SMT }\end{array}$ & $\begin{array}{l}\text { Reduced bowel and psychological symptoms at } \\
\text { EOT and } 6 \text { mo FU }\end{array}$ & Heymann-Mönnikes et al. ${ }^{271}$ \\
\hline $\mathrm{n}=95$ & CBT vs. relaxation vs. SMT & All groups equivalent & Boyce et al. 195 \\
\hline \multicolumn{4}{|l|}{ Hypnosis } \\
\hline $\mathrm{n}=30$ & $\begin{array}{l}\text { Individual hypnosis vs. placebo } \\
\text { pill }+ \text { supportive } \\
\text { psychotherapy }\end{array}$ & $\begin{array}{l}\text { Greater improvement in bowel symptoms and well- } \\
\text { being at EOT and } 18 \text { mo FU }\end{array}$ & Whorwell et al.191,192 \\
\hline \multicolumn{4}{|c|}{ Relaxation/stress management } \\
\hline $\mathrm{n}=20$ & $\begin{array}{l}\text { Relaxation by autogenic training } \\
\text { vs. SMT }\end{array}$ & $\begin{array}{l}\text { Decreased pain and medical clinic visits at EOT } \\
\text { and } 40 \text { mo FU }\end{array}$ & Voirol and Hipolito 272 \\
\hline $\mathrm{n}=35$ & $\begin{array}{l}\text { Relaxation and stress } \\
\text { management vs. SMT }\end{array}$ & Improved bowel symptoms at EOT and 12 mo FU & Shaw et al. ${ }^{273}$ \\
\hline
\end{tabular}

EOT, end of treatment; FU, follow-up; SMT, standard medical treatment; CBT, cognitive behavior therapy.

psychotics and mood stabilizers (for which there is little evidence for benefit in IBS) may be prescribed by psychiatrists consulting on patients with IBS.

Antidepressants. Several antidepressants are prescribed in IBS: TCAs (e.g., amitriptyline, desipramine, imipramine, doxepin), SSRIs (e.g., fluoxetine, sertraline, paroxetine, citalopram), or less frequently, novel antidepressants (e.g., venlaxafine, mirtazapine). The rationale includes: (1) treatment of psychiatric comorbidity (e.g., major depression, anxiety disorders usually using full therapeutic doses) associated with IBS, ${ }^{199-201}$ (2) alteration of GI physiology (e.g., visceral sensitivity, motility, and secretion), ${ }^{202-206}$ or (3) reduction of central pain perception arising from afferent signals in the gut. ${ }^{207-209}$ There is also some evidence that antidepressants may be synergistic with psychological treatment for medical ${ }^{210}$ and psychiatric ${ }^{211}$ disorders. They may improve the motivation for psychologic treatments, which may increase compliance with the medication. Although full antidepressant doses of TCAs are used less frequently today for the treatment of psychiatric conditions (mainly because of their high side effect rates), they are commonly prescribed in smaller doses for the treatment of a variety of chronic pain conditions and functional disorders, including IBS. ${ }^{212}$

Several randomized controlled trials of TCA medications in IBS have been published ${ }^{100}$ and were evaluated in a meta-analysis. ${ }^{212}$ Improvement in global GI symptoms against placebo was highly significant (odds ratio, 4.2; 95\% confidence interval, 2.3-7.9), and there was also improvement in standardized pain scores by $0.9 \mathrm{SD}$ (95\% confidence interval, 0.6-1.2). Furthermore, only 
Table 9. Comparison of Tricyclic and SSRI Antidepressants

\begin{tabular}{|c|c|c|c|}
\hline & Low-dose TCA & SSRI & High-dose TCA \\
\hline \multirow[t]{5}{*}{ Compounds (dose range) } & Amitriptyline (10-50 mg) & Fluoxetine (10-20 mg) & Desipramine (100-200 mg) \\
\hline & Imipramine (10-50 mg) & Sertraline (25-100 mg) & Nortriptyline (100-200 mg) \\
\hline & Doxepin (10-50 mg) & Paroxetine (20-40 mg) & \\
\hline & Desipramine (10-50 mg) & Citalopram (20-40 mg) & \\
\hline & Nortriptyline (10-50 mg) & & \\
\hline Potential benefits & Pain, sleep disturbance & Depression, panic, anxiety, OCD & Pain, depression, anxiety \\
\hline \multirow{9}{*}{$\begin{array}{l}\text { Time to onset of } \\
\text { therapeutic effect } \\
\text { Adverse events }\end{array}$} & Days-2 weeks & $4-6$ weeks & 4-6 weeks \\
\hline & & & \\
\hline & Sedation, constipation & Insomnia & Sedation \\
\hline & & Agitation & Hypotension Constipation \\
\hline & & Diarrhea & \\
\hline & Dry mouth/eyes & & Dry mouth/eyes \\
\hline & & Night sweats & Arrhythmias \\
\hline & Weight gain & Weight loss & Weight gain \\
\hline & Rare sexual dysfunction & Sexual dysfunction & Sexual dysfunction \\
\hline Risk from overdose & Moderate & Minimal & Moderate \\
\hline \multirow[t]{2}{*}{ Efficacy } & Good & Not well studied & Good \\
\hline & & Excellent (affective disorders) & Excellent (affective disorders) \\
\hline Dose adjustment & Yes & Not usual & Yes \\
\hline Cost/month & $\$ 5-20$ & $\$ 60-100$ & $\$ 10-30$ \\
\hline
\end{tabular}

OCD, obsessive-compulsive disorder.

3.2 patients needed to be treated to improve symptoms in 1 patient. In general, even though a wide range of doses were used in these studies, TCA dosages were lower than that used to treat major depression, suggesting that the therapeutic effect was largely unrelated to the TCA's antidepressant effects. The study limitations (e.g., small sample sizes, short study lengths, variable study design quality, use of outcome measures and medication dosages, large losses to follow-up, failure to assess effectiveness of blinding, whether the benefits relate to improvement in comorbid psychiatric disorders) indicate that better-designed studies are needed to determine the mechanism of benefit and the subpopulations most amenable to treatment.

Table 9 compares the TCAs and provides prescribing recommendations. In general, TCAs have more established benefit over SSRIs. Because antidepressants are used on a continual, rather than an "as needed" basis, they are usually prescribed for patients having chronic or frequently recurring symptoms. Low doses of TCAs (e.g., $10-50 \mathrm{mg} /$ day) are recommended for treatment of pain and sleep difficulties associated with IBS, presumably because of their multiple receptor blocking effects (anticholinergic, antihistaminergic, antiadrenergic) in addition to their nonselective monoamine uptake inhibition (serotonin, noradrenaline). ${ }^{213}$ Low doses of TCAs also lead to a more rapid onset of action than full doses used for treating major depression. They are also inexpensive and do not carry the potentially serious cardiovascular side effects associated with full antidepressant doses.
However, there is some evidence ${ }^{203}$ that full dosages of TCAs may also provide benefits when lower dosages are not effective. Notable side effects to the use of high-dose TCAs include sedation, hypotension, and constipation, among others (particularly for amitriptyline, doxepin, and imipramine, over desipramine or nortriptyline), and there is a greater need for dosage adjustments and a greater risk for overdose. If used in higher doses, physicians should be aware of these risks and monitor their patient expectantly.

There are no published controlled studies on the use of SSRIs or novel antidepressants for IBS. However, studies of patients with other painful medical conditions suggest clinical benefits even in the absence of depression, ${ }^{214,215}$ and these agents may have an advantage over TCAs for treating other comorbid psychiatric disorders (e.g., obsessive-compulsive disorder, anxiety disorders, and phobias). Furthermore, physiological studies suggest that they accelerate intestinal transit, ${ }^{206}$ although the therapeutic value of such peripheral effects remains to be determined.

SSRIs are often prescribed particularly for older patients because of their lower side effect profile. They also are superior in treating associated emotional symptoms of anxiety, panic, obsessional behaviors, and constipation-predominant IBS. Specific agents may be considered: fluoxetine has a long half life and may be selected when poor compliance is an issue, citalopram has a low side effect profile and may prove beneficial because of peripheral effects on colonic tone and sensitivity in 
IBS, ${ }^{183}$ and paroxetine, because of its greater anticholinergic effect, may be selected for patients with diarrhea.

In addition, there are other, novel antidepressants, such as mirtazapine, which has the potentially beneficial $5-\mathrm{HT}_{3}$ receptor blocking effect and is particularly indicated in the patient with poor sleep and inability to gain weight. Venlaxafine produces combined serotonin and norepinephrine uptake inhibition and has been shown to increase stimulated pain thresholds ${ }^{216}$; it has been suggested for treatment of certain chronic painful disorders. ${ }^{217}$

Anxiolytic medications (benzodiazepines or azapirones) have sometimes been prescribed for patients with IBS because of the frequent comorbidity of anxiety disorders with $\mathrm{IBS}^{218}$ and many recognize that acute psychological distress can make bowel symptoms worse. Two small studies support the efficacy of benzodiazepines for IBS, ${ }^{219,220}$ but the drug-placebo difference was relatively small. In view of weak treatment effects and a potential for physical dependence and interaction with other drugs, caution should be used when prescribing benzodiazepine anxiolytics, and when prescribed, it should be for a self-limited period of 1-3 weeks. More recently, there is preliminary evidence suggesting that $5-\mathrm{HT}_{1}$ agonists like buspirone may have a role in decreasing GI symptoms because of their effects on relaxing visceral organs. ${ }^{181,221}$ However, it is not clear if central or peripheral effects mediate the therapeutic effects in IBS, and further studies are needed to confirm these initial impressions.

It is important to communicate the value of centrally acting drugs in treating symptoms of IBS within the context of an effective physician-patient relationship. Several guidelines are recommended. ${ }^{100,153}$

Address patient perceptions and expectations for taking antidepressants. Some patients may refuse to take an antidepressant or may be noncompliant ${ }^{222}$ because they perceive: (1) that they are being treated for a psychiatric problem, (2) that the medication may be addicting or "mind altering," or (3) they do not think the doctor accepts the symptoms as "real." These issues need to be properly addressed and clarified when they occur.

Provide a rationale for medication use that is consistent with the patient's expectations. The patient can be informed that for IBS, antidepressants act as central analgesics that work sooner, and in lower dosages, than when they are used to treat major depression. ${ }^{223}$ The medication reduces visceral afferent activity directly or by facilitating descending inhibitory pathways that control pain; however, it can also help to treat depressive symptoms induced by the illness. ${ }^{153}$
Negotiate a treatment plan. The choice of a particular drug is based on: (1) the target symptoms to be treated, (2) the medication's side effect profile, (3) cost, and (4) the patient's previous experiences and preferences. The patient should be involved in making the selection of a particular medication. The patient should also be informed that benefit may occur no sooner than 3-4 weeks (although benefit can occur sooner), and that side effects, if they occur, tend to diminish in 1-2 weeks. TCAs start with lower dosages (e.g., 25-50 mg) and work up to full therapeutic $(150 \mathrm{mg})$ dosages over several weeks. With SSRIs, only one pill is all that is usually required. Treatment is continued for 6-12 months before tapering, and dosage adjustments are usually mutually determined.

Continue phone contact with the patient to assess compliance and side effects. Because the benefit of the medication will not occur for several weeks, and because side effects occur immediately, it helps to have an initial phone contact with the patient during the first week of treatment (and possibly repeat the phone call 2-3 weeks later). This is done to make decisions about possible dose or medication changes, and if needed, to help motivate the patient to continue the medication. The response to the treatment is not based only on symptom reduction, but also by improvement in daily function, quality of life, and emotional state. If side effects occur, it is best to hold the same dosage or reduce it, and only if required, to switch to another medication (preferably within the same class).224

Consider alternates if treatment response is suboptimal. When symptoms are refractory, switching to a different class of antidepressant may be considered. Occasionally, a low-dose TCA can be combined with an SSRI ${ }^{213}$; there is evidence to suggest an augmenting effect of combining psychological treatment with an antidepressant. ${ }^{211}$

\section{Conclusions}

There is sufficient evidence to conclude that IBS is an important medical disorder with significant impact on those afflicted with regard to symptom severity, disability, and impaired quality of life. Furthermore, the burden to society in terms of direct health care costs and indirect effects including work absenteeism exceeds that of most GI disorders. The authors believe that a compelling need exists for investigations that address the mechanisms for these effects through basic studies, as well as pharmacological and behavioral treatment trials to help ameliorate the suffering of patients so afflicted. Meanwhile, there is some empiric evidence for a diag- 
nostic and hierarchical treatment approach based on predominant symptom type, its severity, and associated clinical and psychosocial features.

DOUGLAS A. DROSSMAN, M.D.
UNC Center for Functional GI and Motility
Disorders
Division of Digestive Diseases
University of North Carolina
Chapel Hill, North Carolina
MICHAEL CAMILLERI, M.D.
Enteric Neuroscience Research Program
Mayo Clinic
Rochester, Minnesota
EMERAN A. MAYER, M.D.
UCLA Mind-Body Collaborative Research Center
UCLA School of Medicine
Los Angeles, California
WILLIAM E. WHITEHEAD, Ph.D.
UNC Center for Functional GI and Motility
Disorders
Division of Digestive Diseases
University of North Carolina
Chapel Hill, North Carolina

\section{References}

1. Drossman DA, Corazziari E, Talley NJ, Thompson WG, Whitehead WE. Rome II. The functional gastrointestinal disorders. Diagnosis, pathophysiology and treatment: a multinational consensus. 2nd ed. McLean, VA: Degnon Associates, 2000.

2. Thompson WG, Longstreth GF, Drossman DA, Heaton KW, Irvine EJ, Mueller-Lissner SA. Functional bowel disorders and functional abdominal pain. Gut 1999;45:||43-II46.

3. Thompson WG, Longstreth GF, Drossman DA, Heaton KW, Irvine EJ, Mueller-Lissner SA. C. Functional bowel disorders and D. Functional abdominal pain. In: Drossman DA, Talley NJ, Thompson WG, Whitehead WE, Corazziari E, eds. Rome II: functional gastrointestinal disorders: diagnosis, pathophysiology, and treatment. 2nd ed. McLean, VA: Degnon Associates, Inc., 2000: 351-432.

4. Drossman DA, Whitehead WE, Camilleri M. Irritable bowel syndrome: a technical review for practice guideline development. Gastroenterology 1997;112:2120-2137.

5. Manning AP, Wyman JB, Heaton KW. How trustworthy are bowel histories? Comparison of recalled and recorded information. BMJ 1976;2:213-214.

6. Heaton KW. Epidemiology of irritable bowel syndrome. Eur J Gastroenterol Hepatol 1994;6:465-469.

7. Hahn B, Watson M, Yan S, Gunput D, Heuijerjans J. Irritable bowel syndrome symptom patterns: frequency, duration, and severity. Dig Dis Sci 1998;43:2715-2718.

8. Talley NJ, Weaver AL, Zinsmeister AR, Melton LJ III. Onset and disappearance of gastrointestinal symptoms and functional gastrointestinal disorders. Am J Epidemiol 1992;136:165-177.

9. Kay L, Jorgensen $\mathrm{T}$, Jensen $\mathrm{KH}$. The epidemiology of irritable bowel syndrome in a random population: prevalence, incidence, natural history and risk factors. J Intern Med 1994;236:23-30.

10. Drossman DA, Sandler RS, McKee DC, Lovitz AJ. Bowel patterns among subjects not seeking health care. Use of a questionnaire to identify a population with bowel dysfunction. Gastroenterology 1982;83:529-534.

11. Thompson WG, Heaton KW. Functional bowel disorders in apparently healthy people. Gastroenterology 1980;79:283-288.

12. Jain AP, Gupta OP, Jajoo UN, Sidhwa HK. Clinical profile of irritable bowel syndrome at a rural based teaching hospital in central India. J Assoc Physicians India 1991;39:385-386.

13. Sandler RS, Drossman DA, Nathan HP, McKee DC. Symptom complaints and health care seeking behavior in subjects with bowel dysfunction. Gastroenterology 1984;87:314-318.

14. Drossman DA, McKee DC, Sandler RS, Mitchell CM, Cramer EM, Lowman BC, Burger AL. Psychosocial factors in the irritable bowel syndrome. A multivariate study of patients and nonpatients with irritable bowel syndrome. Gastroenterology 1988; 95:701-708.

15. Talley NJ, Zinsmeister AR, Van Dyke C, Melton LJ III. Epidemiology of colonic symptoms and the irritable bowel syndrome. Gastroenterology 1991;101:927-934.

16. Heaton KW, O'Donnell LJD, Braddon FEM, Mountford RA, Hughes AO, Cripps PJ. Symptoms of irritable bowel syndrome in a British urban community: consulters and nonconsulters. Gastroenterology 1992;102:1962-1967.

17. Drossman DA, Li Z, Andruzzi E, Temple R, Talley NJ, Thompson WG, Whitehead WE, Janssens J, Funch-Jensen P, Corazziari E, Richter JE, Koch GG. U.S. Householder Survey of functional gastrointestinal disorders: prevalence, sociodemography and health impact. Dig Dis Sci 1993;38:1569-1580.

18. Whitehead WE, Bosmajian L, Zonderman AB, Costa PT Jr, Schuster MM. Symptoms of psychologic distress associated with irritable bowel syndrome. Comparison of community and medical clinic samples. Gastroenterology 1988;95:709-714.

19. Talley NJ, Boyce PM, Jones M. Predictors of health care seeking for irritable bowel syndrome: a population based study. Gut 1997;41:394-398.

20. Mitchell CM, Drossman DA. Survey of the AGA membership relating to patients with functional gastrointestinal disorders. Gastroenterology 1987;92:1282-1284.

21. Russo MW, Gaynes BN, Drossman DA. A national survey of practice patterns of gastroenterologists with comparison to the past two decades. J Clin Gastroenterol 1999;29:339-343.

22. Sperber AD, Carmel S, Atzmon Y, Weisberg I, Shalit $Y$, Neumann L, Fich A, Friger M, Buskila D. Use of the functional bowel disorder severity index (FBDSI) in a study of patients with the irritable bowel syndrome and fibromyalgia. Am J Gastroenterol 2000;95:995-998.

23. Levy RL, Von Korff M, Whitehead WE, Stang P, Saunders K, Jhingran P, Barghout V, Feld AD. Costs of care for irritable bowel syndrome patients in a health maintenance organization. Am J Gastoenterol 2001;96:3122-3129.

24. Whitehead WE, Cheskin LJ, Heller BR, Robinson JC, Crowell MD, Benjamin C, Schuster MM. Evidence for exacerbation of irritable bowel syndrome during menses. Gastroenterology 1990;98: 1485-1489.

25. Burns DG. The risk of abdominal surgery in irritable bowel syndrome (abstr). South Afr Med J 1986;70:91.

26. Everhart JE, Renault PF. Irritable bowel syndrome in office-based practice in the United States. Gastroenterology 1991;100:9981005.

27. Sandler RS. Epidemiology of irritable bowel syndrome in the United States. Gastroenterology 1990;99:409-415.

28. Sandler RS, Everhart JE, Donwitz M, Adams E, Cronin K, Goodman C, Gemmen E, Shah S, Avdic A, Rubin R. The burden of selected digestive diseases in the United States. Gastroenterology 2002;122:1500-1511.

29. Serra J, Azpiroz F, Malagelada JR. Impaired transit and tolerance 
of intestinal gas in the irritable bowel syndrome. Gut 2001;48: 14-19.

30. Kellow JE, Eckersley GM, Jones MP. Enhanced perception of physiological intestinal motility in the irritable bowel syndrome. Gastroenterology 1991;101:1621-1627.

31. Ritchie J. Pain from distension of the pelvic colon by inflating a balloon in the irritable bowel syndrome. Gut 1973;6:105-112.

32. Mertz H, Naliboff B, Munakata J, Niazi N, Mayer EA. Altered rectal perception is a biological marker of patients with irritable bowel syndrome. Gastroenterology 1995;109:40-52.

33. Bradette M, Delvaux M, Staumont G, Fioramonti J, Bueno L, Frexinos J. Evaluation of colonic sensory thresholds in IBS patients using a barostat. Definition of optimal conditions and comparison with healthy subjects. Dig Dis Sci 1994;39:449_ 457.

34. Naliboff BD, Munakata J, Fullerton S, Gracely RH, Kodner A, Harraf F, Mayer EA. Evidence for two distinct perceptual alterations in irritable bowel syndrome. Gut 1997;41:505-512.

35. Sun WM, Read NW, Prior A, Daly JA, Cheah SK, Grundy D. Sensory and motor responses to rectal distension vary according to rate and pattern of balloon inflation. Gastroenterology 1990;99:1008-1015.

36. Prior A, Sorial E, Sun WM, Read NW. Irritable bowel syndrome: differences between patients who show rectal sensitivity and those who do not. Eur J Gastroenterol Hepatol 1993;5:343349.

37. Kellow JE, Eckersley GM, Jones MP. Enhanced perception of physiological intestinal motility in the irritable bowel syndrome. Gastroenterology 1991;101:1621-1627.

38. Whitehead WE, Palsson OS. Is rectal pain sensitivity a biological marker for irritable bowel syndrome: psychological influences on pain perception. Gastroenterology 1998;115:1-10.

39. Whitehead WE, Drossman DA, Diamant N, Toner BB, Bangdiwala SI, Hu Y, Bradshaw B, Leutri F, Mikula K, Jia H. Correlation of changes in clinical pain and abnormal stools with changes in visceral pain thresholds following treatment (abstr). Gastroenterology 2000;118(suppl.2):A128.

40. Trimble KC, Farouk R, Pryde A, Douglas S, Heading RC. Heightened visceral sensation in functional gastrointestinal disease is not site-specific. Evidence for a generalized disorder of gut sensitivity. Dig Dis Sci 1995;40:1607-1613.

41. Zighelboim J, Talley NJ, Phillips SF, Harmsen WS, Zinsmeister AR. Visceral perception in irritable bowel syndrome. Rectal and gastric responses to distension and serotonin type 3 antagonism. Dig Dis Sci 1995;40:819-827.

42. Accarino AM, Azpiroz F, Malagelada JR. Selective dysfunction of mechanosensitive intestinal afferents in irritable bowel syndrome. Gastroenterology 1995;108:636-643.

43. Evans PR, Bennett EJ, Bak Y-T, Tennant CC, Kellow JE. Jejunal sensorimotor dysfunction in irritable bowel syndrome: Clinical and psychosocial features. Gastroenterology 1996;110:393404.

44. Holtmann G, Goebell H, Talley NJ. Functional dyspepsia and irritable bowel syndrome: is there a common pathophysiological basis? Am J Gastroenterol 1997;92:954-959.

45. Kellow JE, Phillips SF, Miller LJ, Zinsmeister AR. Dysmotility of the small intestine in irritable bowel syndrome. Gut 1988;29: $1236-1243$.

46. Whitehead WE, Holtkotter B, Enck P, Hoelzl R, Holmes KD, Anthony J, Shabsin HS, Schuster MM. Tolerance for rectosigmoid distention in irritable bowel syndrome. Gastroenterology 1990;98:1187-1192.

47. Rossel P, Drewes AM, Petersen P, Nielsen J, Arendt-Nielsen L. Pain produced by electric stimulation of the rectum in patients with irritable bowel syndrome: further evidence of visceral hyperalgesia. Scand J Gastroenterol 1999;34:1001-1006.

48. Cook IJ, van Eeden A, Collins SM. Patients with irritable bowel syndrome have greater pain tolerance than normal subjects. Gastroenterology 1987;93:727-733.

49. Chang L, Mayer EA, Johnson T, Fitzgerald, LZ, Naliboff B. Differences in somatic perception in female patients with irritable bowel syndrome with and without fibromyalgia. Pain 2000;84: 297-307.

50. Hiatt RB, Katz L. Mast cells in inflammatory conditions of the gastrointestinal tract. Am J Gastroenterol 1962;37:541-545.

51. Weston AP, Biddle WL, Bhatia PS, Miner PB Jr. Terminal ileal mucosal mast cells in irritable bowel syndrome. Dig Dis Sci 1993;38:1590-1595.

52. O'Sullivan M, Clayton N, Breslin NP, Harman I, Bountra C, McLaren A, O'Morain CA. Increased mast cells in the irritable bowel syndrome. Neurogastroenterol Motil 2000;12:449-457.

53. Salzmann JL, Peltier-Koch F, Bloch F, Petite JP, Camilleri JP. Methods in laboratory investigation: morphometric study of coIonic biopsies: a new method of estimating inflammatory diseases. Lab Invest 1990;60:847-851.

54. Tornblom H, Lindberg G, Nyberg B, Veress B, Inst K. Histopathological findings in the jejunum of patients with severe irritable bowel syndrome (abstr). Gastroenterology 2000;118:A140.

55. O'Sullivan MA, Clayton N, Wong T, Bountra C, Buckley MM, O'Morain CA. Increased inos and nitrotyrosine expression in irritable bowel syndrome (IBS) (abstr). Gastroenterology 2000; 118:A702.

56. Gwee KA, Graham JC, McKendrick MW, Collins SM, Marshall JS, Walters SJ, Read NW. Psychometric scores and persistence of irritable bowel after infectious diarrhoea. Lancet 1996;347: 150-153.

57. McKendrick MW, Read NW. Irritable bowel syndrome_-post salmonella infection. J Infect 1994;29:1-3.

58. McKendrick MW. Post Salmonella irritable bowel syndrome-5 year review. J Infect 1996;32:170-171.

59. Neal KR, Hebden J, Spiller R. Prevalence of gastrointestinal symptoms six months after bacterial gastroenteritis and risk factors for development of the irritable bowel syndrome: postal survey of patients. BMJ 1997;7083:779-782.

60. Chaudhary NA, Truelove SC. The irritable colon syndrome. A study of the clinical features, predisposing causes, and prognosis in 130 cases. Q J Med 1962;31:307-322.

61. Longstreth GF, Hawkey CJ, Mayer EA, Jones RH, Naesdal J, Wilson IK, Peacock RA, Wiklund IK. Characteristics of patients with irritable bowel syndrome recruited from three sources: implications for clinical trials. Aliment Pharmacol Ther 2001;15: 959-964.

62. Rodriguez LA, Ruigomez A. Increased risk of irritable bowel syndrome after bacterial gastroenteritis: cohort study. BMJ 1999;318:565-566.

63. Bergin AJ, Donnelly TC, McKendrick MW, Read NW. Changes in anorectal function in persistent bowel disturbance following salmonella gastroenteritis. Eur J Gastroenterol Hepatol 1993; 5:617-620.

64. Gwee KA, Collins SM, Marshall JS, Underwood JE, Moochala SM, Read NW. Evidence of inflammatory pathogenesis in postinfectious irritable bowel syndrome (abstr). Gastroenterology 2001;114:758.

65. Niaz SK, Sandrasegaran K, Renny FH, Jones BJ. Postinfective diarrhoea and bile acid malabsorption. J R Coll Physicians Lond 1997;31:53-56.

66. Spiller RC, Jenkins D, Thornley JP, Hebden JM, Wright T, Skinner $M$, Neal KR. Increased rectal mucosal enteroendocrine cells, T lymphocytes, and increased gut permeability following acute Campylobacter enteritis and in post-dysenteric irritable bowel syndrome. Gut 2000;47:804-811.

67. Drossman DA. Mind over matter in the postinfective irritable bowel. Gut 1999;44:306-307. 
68. Ogilvie AL, James PD, Atkinson M. Impairment of vagal function in reflux oesophagitis. Q J Med 1985;54:61-74.

69. Smart HL, Atkinson M. Abnormal vagal function in irritable bowel syndrome. Lancet 1987;2:475-478.

70. Aggarwal A, Cutts TF, Abell TL, Cardoso S, Familoni B, Bremer J, Karas J. Predominant symptoms in irritable bowel syndrome correlate with specific autonomic nervous system abnormalities. Gastroenterology 1994;106:945-950.

71. Tache Y, Martinez V, Million M, Wang L. Stress and the gastrointestinal tract: III. Stress-related alterations of gut motor function: role of brain-corticotropin-releasing factor receptors. Am J Physiol Gastrointest Liver Physiol 2001;280:G173-G177.

72. Mayer EA, Naliboff BD, Chang L, Coutinho SV. Stress and the gastrointestinal tract vs. stress and irritable bowel syndrome. Am J Physiol Gastrointest Liver Physiol 2001;280:G519-G524.

73. Thompson JJ, Elsenbruch S, Harnish MJ, Orr WC. Autonomic functioning during REM sleep differentiates IBS symptom subgroups (abstr). Gastroenterology 2001;120:A639.

74. Bouras EP, Camilleri M, Burton DD, Thomforde G, McKinzie S, Zinsmeister AR. Prucalopride accelerates gastrointestinal and colonic transit in patients with constipation without a rectal evacuation disorder. Gastroenterology 2001;120:354-360.

75. Mayer EA. The physiology of gastric storage and emptying. In: Johnson LR, ed. Physiology of the gastrointestinal tract. 3rd ed. New York: Raven, 1994:929-976.

76. Rogers RC, McTigue DM, Hermann GE. Vagovagal reflex control of digestion: afferent modulation by neural and "endoneurocrine" factors. Am J Physiol 1995;268:G1-G10.

77. LeDoux JE. The emotional brain: the mysterious underpinnings of emotional life. New York: Simon \& Schuster, 1996:1-384.

78. Randich A, Gebhart GF. Vagal afferent modulation of nociception. Brain Res Rev 1992;17:77-99.

79. Mayer EA. The neurobiology of stress and gastrointestinal disease. Gut 2000;47:861-869.

80. Nieuwenheuys R. The greater limbic system, the emotional motor system and the brain. In: Hostege G, Bandler R, Saper $\mathrm{CB}$, eds. The emotional motor system. Amsterdam: Elsevier, 1996:627.

81. Rosen SD, Paulesu E, Nihoyannopoulos P, Tousoulis D, Frackowiak RSJ, Frith CD, Jones T, Camici PG. Silent ischemia as a central problem: regional brain activation compared in silent and painful myocardial ischemia. Ann Intern Med 1996;124: 939-949.

82. Kern MK, Shaker R. Cerebral cortical registration of subliminal visceral stimulation. Gastroenterology 2002;122:290-298.

83. Mayer EA, Gebhart GF. Basic and clinical aspects of visceral hyperalgesia. Gastroenterology 1994;107:271-293.

84. Bernstein CN, Niazi N, Robert M, Mertz H, Kodner A, Munakata J, Naliboff B, Mayer EA. Rectal afferent function in patients with inflammatory and functional intestinal disorders. Pain 1996;66: 151-161.

85. Bernstein CN, Rollandelli R, Niazi N, Robert M, Hirsh T, Munakata J, Mayer EA. Characterization of afferent mechanisms in ileoanal pouches. Am J Gastroenterol 1997;92:103-108.

86. Keogh E, Ellery D, Hunt C, Hannent I. Selective attentional bias for pain-related stimuli amongst pain fearful individuals. Pain 2001;91:91-100.

87. Accarino AM, Azpiroz F, Malagelada JR. Attention and distraction: effects on gut perception. Gastroenterology 1997;113: 415-422.

88. Rainville P, Duncan GH, Price DD, Carrier B, Bushnell MC. Pain affect encoded in human anterior cingulate but not somatosensory cortex. Science 1997;277:968-971.

89. Coutinho SV, Plotsky P, Sablad M, Miller JC, Zhou H, Bayati Al, McRoberts JA, Mayer EA. Neonatal maternal separation alters stress-induced responses to viscerosomatic nociceptive stimuli in rat. Am J Physiol Gastrointest Liver Physiol 2002;282:G307G316.

90. Heinrichs SC, Tache Y. Therapeutic potential of CRF receptor antagonists: a gut-brain perspective. Expert Opin Investig Drugs 2001;10:647-659.

91. Tache Y, Martinez V, Million M, Maillot C. Role of corticotropin releasing factor subtype 1 in stress-related functional colonic alterations: implications in irritable bowel syndrome. Eur J Surg (in press).

92. Silverman DHS, Munakata JA, Ennes H, Mandelkern MA, Hoh CK, Mayer EA. Regional cerebral activity in normal and pathologic perception of visceral pain. Gastroenterology 1997;112: 64-72.

93. Naliboff BD, Derbyshire SWG, Munakata J, Berman S, Mandelkern M, Chang L, Mayer EA. Cerebral activation in irritable bowel syndrome patients and control subjects during rectosigmoid stimulation. Psychosom Med 2001;63:365-375.

94. Mertz H, Tanner G, Morgan V, Pickens D, Price R, Kessler D. Functional MRI detects activation of anterior cingulate and prefrontal cortex in IBS patients and control subjects during rectosigmoid stimulation (abstr). Gastroenterology 1999;116: A1041.

95. Baciu MV, Bonaz BL, Papillon E, Bost RA, Le Bas JF, Fournet J, Segebarth CM. Central processing of rectal pain: a functional MRI study. AJNR Am J Neuroradiol 1999;20:1920-1924.

96. Hobday DI, Aziz Q, Thacker N, Hollander I, Jackson A, Thompson DG. A study of the cortical processing of ano-rectal sensation using functional MRI. Brain 2001;124:361-368.

97. Vogt BA, Nimchinsky EA, Vogt LJ, Hof PR. Human cingulate cortex: surface features, flat maps, and cytoarchitecture. J Comp Neurol 1995;359:490-506.

98. Bush G, Luu P, Posner MI. Cognitive and emotional influences in anterior cingulate cortex. Trends Cogn Sci 2000;4:215-222.

99. Rainville P, Hofbauer RK, Paus T, Duncan GH, Bushnell MC, Price DD. Cerebral mechanisms of hypnotic induction and suggestion. J Cogn Neurosci 1999;11:110-125.

100. Drossman DA, Creed FH, Olden KW, Svedlund J, Toner BB, Whitehead WE. Psychosocial aspects of the functional gastrointestinal disorders. In: Drossman DA, Corazziari E, Talley NJ, Thompson WG, Whitehead WE, eds. Rome II. The functional gastrointestinal disorders: diagnosis, pathophysiology and treatment; a multinational consensus. 2nd ed. Degnon and Associates, 2000:157-245.

101. Ford MJ, Miller PM, Eastwood J, Eastwood MA. Life events, psychiatric illness and the irritable bowel syndrome. Gut 1987; 28:160-165.

102. Mendeloff Al, Monk M, Siegel Cl, Lilienfeld A. Illness experience and life stresses in patients with irritable colon and with ulcerative colitis. An epidemiologic study of ulcerative colitis and regional enteritis in Baltimore, 1960-1964. N Engl J Med 1970;282:14-17.

103. Fava GA, Pavan L. Large bowel disorders. I. Illness configuration and life events. Psychother Psychosom 1976;27:93.

104. Whitehead WE, Crowell MD, Robinson JC, Heller BR, Schuster MM. Effects of stressful life events on bowel symptoms: subjects with irritable bowel syndrome compared to subjects without bowel dysfunction. Gut 1992;33:825-830.

105. Walker LS, Garber J, Smith CA, Van Slyke DA, Claar RL. The relation of daily stressors to somatic and emotional symptoms in children with and without recurrent abdominal pain. J Consult Clin Psychol 2001;69:85-91.

106. Dinan TG, O'Keane V, O'Boyle C, Chua A, Keeling PW. A comparison of the mental status, personality profiles and life events of patients with irritable bowel syndrome and peptic ulcer disease. Acta Psychiatr Scand 1991;84:26-28.

107. Levy RL, Cain KC, Jarrett M, Heitkemper MM. The relationship between daily life stress and gastrointestinal symptoms in 
women with irritable bowel syndrome. J Behav Med 1997;20: 177-193.

108. Drossman DA, Leserman J, Nachman G, Li Z, Gluck H, Toomey TC, Mitchell CM. Sexual and physical abuse in women with functional or organic gastrointestinal disorders. Ann Intern Med 1990;113:828-833.

109. Drossman DA, Li Z, Leserman J, Toomey TC, Hu Y. Health status by gastrointestinal diagnosis and abuse history. Gastroenterology 1996;110:999-1007.

110. Creed FH, Craig T, Farmer RG. Functional abdominal pain, psychiatric illness and life events. Gut 1988;29:235-242.

111. Welgan $\mathrm{P}$, Meshkinpour $\mathrm{H}$, Beeler M. Effect of anger on colon motor and myoelectric activity in irritable bowel syndrome. Gastroenterology 1988;94:1150-1156.

112. Talley NJ, Phillips SF, Bruce B, Twomey CK, Zinsmeister AR, Melton LJ. Relation among personality and symptoms in nonulcer dyspepsia and the irritable bowel syndrome. Gastroenterology 1990;99:327-333.

113. Blanchard EB, Radnitz CL, Evans DD, Schwartz SP, Neff DF, Gerardi MA. Psychological comparisons of irritable bowel syndrome to chronic tension and migraine headache and nonpatient controls. Biofeedback Self Reg 1986;11:221-230.

114. Ali A, Toner BB. Sexual abuse and self-blame in women with irritable bowel syndrome (abstr). Psychosom Med 1996;58:66.

115. Toner BB, Garfinkel PE, Jeejeebhoy KN, Scher H, Shulhan D, Gasbarro ID. Self-schema in irritable bowel syndrome and depression. Psychosom Med 1990;52:149-155.

116. Toner BB, Koyama E, Garfinkel PE, Jeejeebhoy KN, Gasbarro I. Social desirability and irritable bowel syndrome. Int J Psychiatr Med 1992;22:99-103.

117. Sperber AD, Carmel S, Atzmon Y, Weisberg I, Shalit Y, Neumann L, Fich A, Buskila D. The sense of coherence index and the irritable bowel syndrome: a cross-sectional comparison among IBS patients with and without coexisiting fibromyalgia, IBS nonpatient and controls. Scand J Gastroenterol 1999;34:259263.

118. Ali A, Toner BB, Stuckless N, Gallop R, Diamant NE, Gould M, Vidins E. Emotional abuse, self-blame and self-silencing in women with irritable bowel syndrome. Psychosom Med 2000; 62:76-82.

119. Drossman DA, Li Z, Leserman J, Keefe FJ, Hu YJ, Toomey TC. Effects of coping on health outcome among female patients with gastrointestinal disorders. Psychosom Med 2000;62:309-317.

120. Longstreth GF, Wolde-Tsadik G. Irritable bowel-type symptoms in HMO examinees. Prevalence, demographics, and clinical correlates. Dig Dis Sci 1993;38:1581-1589.

121. Talley NJ, Fett SL, Zinsmeister AR, Melton LJ. Gastrointestinal tract symptoms and self-reported abuse: a population-based study. Gastroenterology 1994;107:1040-1049.

122. Bennett EJ, Tennant CC, Piesse C, Badcock CA, Kellow JE. Level of chronic life stress predicts clinical outcome in irritable bowel syndrome. Gut 1998;43:256-261.

123. Fowlie S, Eastwood MA, Ford MJ. Irritable bowel syndrome: the influence of psychological factors on the symptom complex. J Psychosom Res 1992;36:169-173.

124. Blanchard EB, Schwartz SP, Neff DF, Gerardi MA. Prediction of outcome from the self-regulatory treatment of irritable bowel syndrome. Behav Res Ther 1988;26:187-190.

125. Levy RL, Whitehead WE, Von Korff MR, Saunders KW, Feld AD. Intergenerational transmission of Gl illness behavior. Am J Gastroenterol 1998;95:451-456.

126. Levy RL, Jones KR, Whitehead WE, Feld SI, Talley NJ, Corey LA. Irritable bowel syndrome in twins: heredity and social learning both contribute to etiology. Gastroenterology 2001;121:799804.

127. Whitehead WE, Crowell MD, Heller BR, Robinson JC, Schuster $\mathrm{MM}$, Horn S. Modeling and reinforcement of the sick role during childhood predicts adult illness behavior. Psychosom Med 1994;56:541-550.

128. Whitehead WE, Winget C, Fedoravicius AS, Wooley S, Blackwell B. Learned illness behavior in patients with irritable bowel syndrome and peptic ulcer. Dig Dis Sci 1982;27:202-208.

129. Lowman BC, Drossman DA, Cramer EM, McKee DC. Recollection of childhood events in adults with irritable bowel syndrome. J Clin Gastroenterol 1987;9:324-330.

130. Koloski NA, Talley NJ, Boyce PM. The impact of functional gastrointestinal disorders on quality of life. Am J Gastroenterol 2000;95:67-71.

131. Guyatt GH, Feeny DH, Patrick DL. Measuring health-related quality of life. Ann Intern Med 1993;118:622-629.

132. Yacavone RF, Locke GR III, Provenzale DT, Eisen GM. Quality of life measurement in gastroenterology: what is available? Am J Gastroenterol 2001;96:285-297.

133. Luscombe FA. Health-related quality of life and associated psychosocial factors in irritable bowel syndrome: a review. Qual Life Res 2000;9:161-176.

134. Drossman DA, Patrick DL, Whitehead WE, Toner BB, Diamant $\mathrm{NE}$, Hu YJB, Jia H, Bangdiwala SI. Further validation of the IBS-QOL: a disease specific quality of life questionnaire. Am J Gastoenterol 2000;95:999-1007.

135. Groll D, Vanner SJ, Depew WT, DaCosta LR, Simon JB, Groll A, Roblin N, Paterson WG. The IBS-36: a new quality of life measure for irritable bowl syndrome. Am J Gastroenterol 2002;97: 962-971.

136. Gralnek IM, Hays RD, Kilbourne A, Naliboff B, Mayer E. The impact of irritable bowel syndrome on health-related quality of life. Gastroenterology 2000;119:655-660.

137. Whitehead WE, Burnett CK, Cook E III, Taub E. Impact of irritable bowel syndrome on quality of life. Dig Dis Sci 1996;41:22482253.

138. Patrick DL, Drossman DA, Frederick IO, DiCesare J, Puder KL. Quality of life in persons with irritable bowel syndrome: development of a new measure. Dig Dis Sci 1998;43:400-411.

139. Hahn BA, Kirchdoerfer LJ, Fullerton S, Mayer E. Evaluation of a new quality of life questionnaire for patients with irritable bowel syndrome. Aliment Pharmacol Ther 1997;11:547-552.

140. Whitehead WE, Wald A, Diamant N, Enck P, Pemberton J, Rao SSC. Functional disorders of the anus and rectum. In: Drossman DA, Corazziari E, Talley NJ, Thompson WG, Whitehead WE, eds. Rome II. Functional gastrointestinal disorders: diagnosis, pathophysiology and treatment: a multinational consensus. 2nd ed. McLean, VA: Degnon Associates, 2000:483-532.

141. Vanner SJ, Depew WT, Paterson W, DaCosta LR, Groll AG, Simon JB, Djurfeldt M. Predictive value of the Rome Criteria for diagnosing the irritable bowel syndrome. Am J Gastroenterol 1999;94:2912-2917.

142. Fass R, Longstreth G, Pimentel M, Fullerton S, Russak SM, Chiou CF, Reyes E, Crane P, Eisen G, McCarberg B, Ofman J. Evidence- and consensus-based practice guidelines for the diagnosis of irritable bowel syndrome. Arch Intern Med 2001; 161:2081-2088.

143. Drossman DA. Irritable bowel syndrome: How far do you go in the workup? Gastroenterology 2001;121:1512-1515.

144. Hamm LR, Sorrells SC, Harding JP, Northcutt AR, Heath A, Kapke GF, Hunt CM, Mangel AW. Additional investigations fail to alter the diagnosis of irritable bowel syndrome in subjects fulfilling the Rome criteria. Am J Gastroenterol 1999;94:12791282.

145. Ciclitira PJ. American Gastroenterological Association medical position statement: celiac sprue. Gastroenterology 2001;120: 1522-1525.

146. Wahnschaffe U, Ullrich R, Riecken EO, Schulzke JD. Celiac disease-like abnormalities in a subgroup of patients with irritable bowel syndrome. Gastroenterology 2001;121:1329-1338. 
147. Sanders DS, Carter MJ, Hurlstone DP, Pearce A, Ward AM, McAlindon ME, Lobo AJ. Association of adult coeliac disease with irritable bowel syndrome: a case-control study in patients fulfilling ROME II criteria referred to secondary care. Lancet 2001;358:1504-1508.

148. Tolliver BA, Herrera JL, DiPalma JA. Evaluation of patients who meet clinical criteria for irritable bowel syndrome. Am J Gastroenterol 1994;89:176-178.

149. Pimentel M, Chow EJ, Lin HC. Eradication of small intestinal bacterial overgrowth reduces symptoms of irritable bowel syndrome. Am J Gastroenterol 2000;95:3503-3506.

150. Drossman DA, Whitehead WE, Toner BB, Diamant NE, Hu YJB, Bangdiwala $\mathrm{SI}$, Jia $\mathrm{H}$. What determines severity among patients with painful functional bowel disorders? Am J Gastroenterol 2000;95:974-980.

151. Drossman DA, Li Z, Toner BB, Diamant NE, Creed FH, Thompson DG, Read NW, Babbs C, Barreiro M, Bank L, Whitehead WE, Schuster MM, Guthrie EA. Functional bowel disorders: a multicenter comparison of health status, and development of illness severity index. Dig Dis Sci 1995;40:986-995.

152. Shapiro MS, Olden KW. Symptom expression in pain-predominant functional bowel syndrome: is visceral hyperalgesia the whole truth? Am J Gastroenterol 2000;95:862-863.

153. Drossman DA. Diagnosing and treating patients with refractory functional gastrointestinal disorders. Ann Intern Med 1995; 123:688-697.

154. Drossman DA, Thompson WG. The irritable bowel syndrome: review and a graduated, multicomponent treatment approach. Ann Intern Med 1992;116:1009-1016.

155. Owens DM, Nelson DK, Talley NJ. The irritable bowel syndrome: long term prognosis and the physician-patient interaction. Ann Intern Med 1995;122:107-112.

156. O'Sullivan MA, Mahmud N, Kelleher DP, Lovett E, O'Morain CA. Patient knowledge and educational needs in irritable bowel syndrome. Eur J Gastroenterol Hepatol 2000;12:39-43.

157. Jackson JL, Kroenke K. The effect of unmet expectations among adults presenting with physical symptoms. Ann Intern Med 2001;134:889-897.

158. Lucey MR, Clark ML, Lowndes J, Dawson AM. Is bran efficacious in irritable bowel syndrome? A double-blind placebo-controlled crossover study. Gut 1987;28:221-225.

159. Cook IJ, Irvine EJ, Campbell D, Shannon S, Reddy SN, Collins $\mathrm{SM}$. Effect of dietary fiber on symptoms and rectosigmoid motility in patients with irritable bowel syndrome. Gastroenterology 1990;98:66-72.

160. Shimberg EF. Relief from IBS. 1st ed. New York: M. Evans and Company, 1988:258.

161. Klein KB. Controlled treatment trials in the irritable bowel syndrome: a critique. Gastroenterology 1988;95:232-241.

162. Poynard T, Naveau S, Mory B, Chaput JC. Meta-analysis of smooth muscle relaxers in the treatment of irritable bowel syndrome. Aliment Pharmacol Ther 1994;8:499-510.

163. Jailwala J, Imperiale TF, Kroenke K. Pharmacologic treatment of the irritable bowel syndrome: a systematic review of randomized, controlled trials. Ann Intern Med 2000;133:136-147.

164. Poynard T, Regimbeau C, Benhamou Y. Meta-analysis of smooth muscle relaxants in the treatment of irritable bowel syndrome. Aliment Pharmacol Ther 2001;15:355-361.

165. Akehurst R, Kaltenthaler E. Treatment of irritable bowel syndrome: a review of randomised controlled trials. Gut 2001;48: 272-282.

166. Pittler MH, Ernst E. Peppermint oil for irritable bowel syndrome: a critical review and metaanalysis. Am J Gastroenterol 1998; 93:1131-1135.

167. Read M, Read NW, Barber DC, Duthie HL. Effects of loperamide on anal sphincter function in patients complaining of chronic diarrhea with fecal incontinence and urgency. Dig Dis Sci 1982; 27:807-814.

168. Kozlowski CM, Green A, Grundy D, Boissonade FM, Bountra C. The $5-\mathrm{HT}_{3}$ receptor antagonist alosetron inhibits the colorectal distention induced depressor response and spinal $c$-fos expression in the anaesthetized rat. Gut 2000;46:474-480.

169. Camilleri M, Mayer EA, Drossman DA, Heath AT, Dukes GE, McSorley D, Kong S, Mangel AW, Northcutt AR. Improvement in pain and bowel function in female irritable bowel patients with alosetron, a $5-\mathrm{HT}_{3}$ receptor antagonist. Aliment Pharmacol Ther 1999;13:1149-1159.

170. Bardhan KD, Bodemar G, Geldof H, Schutz E, Heath A, Mill JG, Jacques LA. A double-blind, randomized, placebo-controlled dose-ranging study to evaluate the efficacy of alosetron in the treatment of irritable bowel syndrome. Aliment Pharmacol Ther 2000;14:23-34.

171. Camilleri M, Northcutt AR, Kong S, Dukes GE, McSorley D, Mangel AW. Efficacy and safety of alosetron in women with irritable bowel syndrome: a randomised, placebo-controlled trial. Lancet 2000;355:1035-1040.

172. Mangel AW, Camilleri M, Chey WY, Mayer EA, Northcutt AR, Heath AT, Dukes GE, McSorley D. Alosetron, a 5-HT3 receptor antagonist, in the treatment of non-constipated female IBS patients (abstr). Am J Gastroenterol 1999;94:2677.

173. Caras S, Krause G, Biesheuvel E, Steinborn C. Cilansetron shows efficacy in male and female non-constipated patients with irritable bowel syndrome in a United States study (abstr). Gastroenterology 2001;120:A217.

174. Mueller-Lissner S, Fumagalli I, Bardhan KD, Pace F, Nault B, Pecher EC, Rueegg PC, Lefkowitz MP. Tegaserod, a 5- $\mathrm{HT}_{4}$ receptor partial agonist, relieves key symptoms of irritable bowel syndrome (abstr). Gastroenterology 2000;118:A175.

175. Briejer E, Ghoos E, Eelen J, Schuurkes JAJ. Serotonin 5-HT receptors mediate the R093877-induced changes in contractile patterns in the canine colon (abstr). Gastroenterology 1997; 112:A705

176. Emmanuel AV, Kamm MA, Roy AJ, Antonelli K. Effect of a novel prokinetic drug, R093877, on gastrointestinal transit in healthy volunteers. Gut 1998;42:511-516.

177. Bouras EP, Camilleri M, Burton DD, McKinzie S. Selective stimulation of colonic transit by the benzofuran $5-\mathrm{HT}_{4}$ agonist, prucalopride, in healthy humans. Gut 1999;44:682-686.

178. Johanson J, Miner PB, Parkman HP, Wojcik MA, Lambert R, Karcher K, Woods M. Prucalopride improves bowel movement frequency and symptoms in patients with chronic constipation: results of two double-blind, placebo-controlled trials (abstr). Gastroenterology 2000;118:A175.

179. Miner PB, Nichols T Jr, Silvers DR, Joslyn A, Woods M. The efficacy and safety of prucalopride in patients with chronic constipation (abstr). Gastroenterology 1999;116:A1043.

180. Bharucha AE, Camilleri M, Zinsmeister AR, Hanson RB. Adrenergic modulation of human colonic motor and sensory function. Am J Physiol 1997;273:G997-G1006.

181. Tack J, Piessevaux H, Coulie B, Fischler B, De Gucht V, Janssens J. A placebo-controlled trial of buspirone, a fundus-relaxing drug, in functional dyspepsia: effect on symptoms and gastric sensory and motor function (abstr). Gastroenterology 1999; 116:A325.

182. Tack JF, Vos R, Broekaert D, Fischler B, Janssens J. Influence of citalopram, a selective serotonin reuptake inhibitor, on colonic tone and sensitivity in man (abstr). Gastroenterology 2000; 118:A175.

183. Broekaert D, Vos R, Gevers AM, Janssens J, Vandenberghe J, Fischler B, Tack J. A double-blind randomised placebo-controlled crossover trial of citalopram, a selective 5-hydroxytryptamine reuptake inhibitor, in irritable bowel syndrome (abstr). Gastroenterology 2001;120:A641. 
184. Smart HL, Mayberry JF, Atkinson M. Alternative medicine consultations and remedies in patients with the irritable bowel syndrome. Gut 1986;27:826-828.

185. Sloth $\mathrm{H}$, Mortensen $\mathrm{NH}$, Bisgard C. Irritable colon and ulcerative colitis. Alternative treatment is used frequently. Ugeskr Laeger 1991;153:3304-3306.

186. Verhoef MJ, Sutherland LR, Brkich L. Use of alternative medicine by patients attending a gastroenterology clinic. Can Med Assoc J 1990;142:121-125.

187. Sutherland LR, Verhoef MJ. Why do patients seek a second opinion or alternative medicine? J Clin Gastroenterol 1994;19: 194-197.

188. Bittinger M, Barnert J, Wienbeck M. Alternative therapy methods in functional disorders of the gastrointestinal system. Zeitschrift fur Gastroenterologie 1998;36:519-524.

189. Bensoussan A, Talley NJ, Hing M, Menzies R, Guo A, Ngu M. Treatment of irritable bowel syndrome with Chinese herbal medicine: a randomized controlled trial. JAMA 1998;280:15851589.

190. Payne A, Blanchard EB. A controlled comparison of cognitive therapy and self-help support groups in the treatment of irritable bowel syndrome. J Consult Clin Psychol 1995;63:779-786.

191. Whorwell PJ, Prior A, Faragher EB. Controlled trial of hypnotherapy in the treatment of severe refractory irritable bowel syndrome. Lancet 1984;2:1232-1233.

192. Whorwell PJ, Prior A, Colgan SM. Hypnotherapy in severe irritable bowel syndrome: further experience. Gut 1987;28:423425.

193. Toner BB, Segal ZV, Emmott S, Myran D, Ali A, DiGasbarro I, Stuckless N. Cognitive behavior group therapy for patients with irritable bowel syndrome. Int J Group Psychother 1998;48:215243.

194. Blanchard EB, Schwarz SP, Suls JM, Gerardi MA, Scharff L, Greene B, Taylor AE, Berreman C, Malamood HS. Two controlled evaluations of multicomponent psychological treatment of irritable bowel syndrome. Behav Res Ther 1992;30:175-189.

195. Boyce PM, Talley NJ, Koloski NA, Balaam B, Nandurkar S. A randomized controlled trial of cognitive behavioural therapy, relaxation therapy and routine medical care for irritable bowel syndrome (IBS) (abstr). Gastroenterology 2001;120:A115.

196. Guthrie E, Creed F, Dawson D, Tomenson B. A controlled trial of psychological treatment for the irritable bowel syndrome. Gastroenterology 1991;100:450-457.

197. Toner BB, Segal ZV, Emmott SD, Myran D. Cognitive-behavioral treatment of irritable bowel syndrome: The brain-gut connection. New York: Guilford Press, 2000:188.

198. Creed F, Ratcliffe J, Fernandez L, Tomenson B, Palmer S, Rigby C, Guthrie E, Read N, Thompson D. Health-related quality of life and health care costs in severe, refractory irritable bowel syndrome. Ann Intern Med 2001;134:860-868.

199. Heefner JD, Wilder RM, Wilson JD. Irritable colon and depression. Psychosomatics 1978;19:540-547.

200. Hislop IG. Psychological significance of the irritable colon syndrome. Gut 1971;12:452-457.

201. Lancaster-Smith MJ, Prout BJ, Pinto T, Anderson JA, Schiff AA. Influence of drug treatment on the irritable bowel syndrome and its interaction with psychoneurotic morbidity. Acta Psychiatr Scand 1982;66:33-41.

202. Su X, Gebhart GF. Effects of tricyclic antidepressants on mechanosensitive pelvic nerve afferent fibers innervating the rat colon. Pain 1998;76:105-114.

203. Greenbaum DS, Mayle JE, Vanegeren LE, Jerome JA, Mayor JW, Greenbaum RB, Matson RW, Stein GE, Dean HA, Halvorsen NA, Rosen LW. The effects of desipramine on IBS compared with atropine and placebo. Dig Dis Sci 1987;32:257-266.

204. Dapoigny M, Abitbol JL, Scherrer B, Fraitag B. "Kapping” vis- ceral pain in patients with irritable bowel syndrome: does it work? Gastroenterology 1996;111:531-533.

205. Gorard DA, Libby GW, Farthing MJG. Effect of a tricyclic antidepressant on small intestinal motility in health and diarrheapredominant irritable bowel syndrome. Dig Dis Sci 1995;40: 86-95.

206. Gorard DA, Libby GW, Farthing MJG. Influence of antidepressants on whole gut orocaecal transit times in health and irritable bowel syndrome. Aliment Pharmacol Ther 1994;8:159166.

207. Onghena P, Houdenhove BV. Antidepressant-induced analgesia in chronic non-malignant pain: a meta-analysis of 39 placebocontrolled studies. Pain 1992;49:205-219.

208. Clouse RE. Antidepressants for functional gastrointestinal syndromes. Dig Dis Sci 1994;39:2352-2363.

209. Mertz H, Fass R, Kodner A, Yan-Go F, Fullerton S, Mayer EA. Effect of amitryptiline on symptoms, sleep, and visceral perception in patients with functional dyspepsia. Am J Gastroenterol 1998;93:160-165.

210. Holroyd KA, O'Donnell FJ, Stensland J, Lipchik GL, Cordingley GE, Carlson BW. Management of chronic tension-type headache with tricyclic antidepressant medication, stress management therapy, and their combination. JAMA 2001;285:2208-2215.

211. Keller MB, McCullough JP, Klein DN, Arnow B, Dunner DL, Gelenberg AJ, Markowitz JC, Nemeroff CB, Russell JM, Thase ME, Trivedi MH, Zajecka J. A comparison of nefazodone, the cognitive behavioral-analysis system of psychotherapy, and their combination for the treatment of chronic depression. N Engl J Med 2000;342:1462-1470.

212. Jackson JL, O'Malley PG, Tomkins G, Balden E, Santoro J, Kroenke K. Treatment of functional gastrointestinal disorders with anti-depressants: A meta-analysis. Am J Med 2000;108: 65-72.

213. Richelson E. Pharmacology of antidepressants. Mayo Clin Proc 2001;76:511-527.

214. Finley PR. Selective serotonin reuptake inhibitors: pharmacologic profiles and potential therapeutic distinctions. Ann Pharmacother 1994;28:1359-1369.

215. Boyer WF. Potential indications for the selective serotonin reuptake inhibitors. Int Clin Psychopharmacol 1992;6(suppl 5): 5-12.

216. Enggaard TP, Klitgaard NA, Gram LF, Arendt-Nielsen L, Sindrup $\mathrm{SH}$. Specific effect of venlafaxine on single and repetitive experimental painful stimuli in humans. Clin Pharmacol Ther 2001;69:245-251.

217. Pernia A, Micó JA, Calderón E, Torres LM. Venlafaxine for the treatment of neuropathic pain. J Pain Symptom Manage 2000; 19:408-410.

218. Lydiard RB, Falsetti SA. Experience with anxiety and depression treatment studies: implications for designing irritable bowel syndrome clinical trials. Am J Med 1999;107:65S-73S.

219. Ritchie JA, Truelove SC. Comparison of various treatments for irritable bowel syndrome. BMJ 1980;281:1317-1319.

220. Baume $P$, Cuthbert J. The effect of medazepam in relieving symptoms of functional gastrointestinal distress. Aust $\mathrm{N} \mathrm{Z}$ J Med 1973;3:457-460.

221. Tack J, Piessevaux H, Coulie B, Caenepeel P, Janssens J. Role of impaired gastric accommodation to a meal in functional dyspepsia. Gastroenterology 1998;115:1346-1352.

222. Cakkues AL, Popkin MK. Antidepressant treatment of medicalsurgical inpatients by nonpsychiatric physicians. Arch Gen Psychiatry 1987;44:157-160.

223. Clouse RE, Lustman P, Geisman RA. Antidepressant therapy in 138 patients with irritable bowel syndrome: a five-year clinical experience. Aliment Pharmacol Ther 1994;8:409-416.

224. Brown WA, Harrison W. Are patients who are intolerant to one 
serotonin selective reuptake inhibitor intolerant to another? J Clin Psychiatry 1995;56:30-34.

225. Jones R, Lydeard S. Irritable bowel syndrome in the general population. BMJ 1992;304:87-90.

226. Zuckerman MJ, Guerra LG, Drossman DA, Foland JA, Gregory GG. Comparison of bowel patterns in Hispanics and non-Hispanic whites. Dig Dis Sci 1995;40:1761-1769.

227. Taub E, Cuevas JL, Cook EW, Crowell M, Whitehead WE. Irritable bowel syndrome defined by factor analysis: gender and race comparisons. Dig Dis Sci 1995;40:2647-2655.

228. Osterberg E, Blomquist L, Krakau I, Weinryb RM, Asberg M, Hultcrantz R. A population study on irritable bowel syndrome and mental health. Scand J Gastroenterol 2000;35:264-268.

229. Boyce PM, Koloski NA, Talley NJ. Irritable bowel syndrome according to varying diagnostic criteria: are the new Rome II criteria unnecessarily restrictive for research and practice? Am J Gastroenterology 2000;95:3176-3182.

230. Talley NJ, Howell S, Poulton R. The irritable bowel syndrome and psychiatric disorders in the community: is there a link? Am J Gastroenterol 2001;96:1072-1079.

231. Thompson WG, Irvine EJ, Pare P, Ferrazzi S, Rance L. Functional gastrointestinal disorders in Canada: first population based survey using Rome II criteria with suggestions for improving the questionnaire. Dig Dis Sci 2002;47:225-235.

232. Van Wijk HJ, Smout AJPM, Akkermans LMA, Roelofs JMM, ten Thije OJ. Gastric emptying and dyspeptic symptoms in the irritable bowel syndrome. Scand J Gastroenterol 1992;27:99102.

233. Evans PR, Bak YT, Shuter B, Hoschl R, Kellow JE. Gastroparesis and small bowel dysmotility in irritable bowel syndrome. Dig Dis Sci 1997;42:2087-2093.

234. Caballero-Plasencia AM, Valenzuela-Barranco M, Herrerias-Gutierez JM, Esteban-Carretero JM. Altered gastric emptying in patients with irritable bowel syndrome. Eur J Nucl Med 1999; 26:404-409.

235. Welgan $\mathrm{P}$, Meshkinpour $\mathrm{H}, \mathrm{Ma} \mathrm{J}$. Role of anger in antral motor activity in irritable bowel syndrome. Dig Dis Sci 2000;45:248251.

236. Leahy A, Besherdas K, Clayman C, Mason I, Epstein O. Abnormalities of the electrogastrogram in functional gastrointestinal disorders. Am J Gastoenterol 1999;94:1023-1028.

237. Kumar D, Wingate DL. The irritable bowel syndrome: a paraxysmal motor disorder. Lancet 1985;2:973-977.

238. Kellow JE, Gill RC, Wingate DL. Prolonged ambulant recordings of small bowel motility demonstrate abnormalities in the irritable bowel syndrome. Gastroenterology 1990;98:1208-1218.

239. Schmidt T, Hackelsberger N, Widmer R, Meisel C, Pfeiffer A, Kaess H. Ambulatory 24-hour jejunal motility in diarrhea-predominant irritable bowel syndrome. Scand J Gastroenterol 1996;31:581-589.

240. Simren M, Castedal M, Svedlund J, Abrahamsson H, Bjornsson E. Abnormal propagation pattern of duodenal pressure waves in the irritable bowel syndrome (IBS). Dig Dis Sci 2000;45:21512161.

241. Gorard DA, Libby GW, Farthing MJG. Ambulatory small intestinal motility in 'diarrhoea' predominant irritable bowel syndrome. Gut 1994;35:203-210.

242. Fukudo S, Nomura T, Hongo M. Impact of corticotropin-releasing hormone on gastrointestinal motility and adrenocorticotropic hormone in normal controls and patients with irritable bowel syndrome. Gut 1998;42:845-849.

243. Kellow JE, Phillips SF. Altered small bowel motility in irritable bowel syndrome is correlated with symptoms. Gastroenterology 1987;92:1885-1893.

244. Kellow JE, Langeluddecke PM, Eckersley GM, Jones MP, Tennant CC. Effects of acute psychologic stress on small-intestinal motility in health and the irritable bowel syndrome. Scand $J$ Gastroenterol 1992;27:53-58.

245. Cann PA, Read NW, Brown C, Hobson N, Holdsworth CG. Irritable bowel syndrome: relationship of disorders in the transit of a single solid meal to symptom patterns. Gut 1983;24:405-411.

246. Lu CL, Chen CY, Chang FY, Lee SD. Characteristics of small bowel motility in patients with irritable bowel syndrome and normal humans: an Oriental study. Chinese Science 1998;95: 165-169.

247. Vassallo MJ, Camilleri M, Phillips SF, Steadman CJ, Talley NJ, Hanson RB, Haddad AC. Colonic tone and motility in patients with irritable bowel syndrome. Mayo Clin Proc 1992;67:725731.

248. Whitehead WE, Drescher VM. Perception of gastric contractions and self-control of gastric motility. Psychophysiology 1980;17: 552-558.

249. Rogers J, Henry MM, Misiewicz JJ. Increased segmental activity and intraluminal pressures in the sigmoid colon of patients with the irritable bowel syndrome. Gut 1989;30:634-641.

250. Fukudo S, Suzuki J. Colonic motility, autonomic function, and gastrointestinal hormones under psychological stress on IBS. Tohoku J Exp Med 1987;151:373-385.

251. Ladabaum U, Minoshima S, Hasler WL, Cross D, Chey WD, Owyang C. Gastric distention correlated with activation of multiple cortical and subcortical regions. Gastroenterology 2001; 120:369-376.

252. Bueno L, Fioramonti J, Ruckebusch Y, Frexinos J, Coulom P. Evaluation of colonic myoelectrical activity in health and functional disorders. Gut 1980;21:480-485.

253. Vassallo M, Camilleri M, Phillips SF, Brown ML, Chapman NJ, Thomforde GM. Transit through the proximal colon influences stool weight in the irritable bowel syndrome. Gastroenterology 1992;102:102-108.

254. Whitehead WE, Crowell MD, Davidoff AL, Palsson OS, Schuster MM. Pain from rectal distension in women with irritable bowel syndrome: relationship to sexual abuse. Dig Dis Sci 1997;42: 796-804.

255. Blomhoff S, Jacobsen MB, Spetalen S, Vatn M, Malt UF. Rectal tone and brain information processing in irritable bowel syndrome. Dig Dis Sci 2000;45:1153-1159.

256. Horikawa $\mathrm{Y}$, Mieno H, Inoue M, Kajiyama G. Gastrointestinal motility in patients with irritable bowel syndrome studied by using radiopaque markers. Scand J Gastroenterol 1999;34: 1190-1195.

257. MacDonald AJ, Bouchier IAD. Non-organic gastrointestinal illness: a medical and psychiatric study. Br J Psychiatry 1980; 136:276-283.

258. Craig TKJ, Brown GW. Goal frustration and life events in the aetiology of painful gastrointestinal disorder. J Psychosom Res 1984;28:411-421.

259. Colgan S, Creed FH, Klass SH. Psychiatric disorder and abnormal illness behaviour in patients with upper abdominal pain. Psychol Med 1988;18:887-892.

260. Corney RH, Stanton R. Physical symptom severity, psychological and social dysfunction in a series of outpatients with irritable bowel syndrome. J Psychosom Res 1990;34:483-491.

261. Toner BB, Garfinkel PE, Jeejeebhoy KN. Psychological factors in irritable bowel syndrome. Can J Psychiatry 1990;35:158-161.

262. Blanchard EB, Scharff L, Schwartz SP, Suls JM, Barlow DH. The role of anxiety and depression in the irritable bowel syndrome. Behav Res Ther 1990;28:401-405.

263. Walker EA, Gelfand AN, Gelfand MD, Katon WJ. Psychiatric diagnoses, sexual and physical victimization, and disability in patients with irritable bowel syndrome or inflammatory bowel disease. Psychol Med 1995;25:1259-1267.

264. Irwin C, Falsetti SA, Lydiard RB, Ballenger JC, Brock CD, Brener 
W. Comorbidity of posttraumatic stress disorder and irritable bowel syndrome. J Clin Psychiatry 1996;57:576-578.

265. Drossman DA. Review article: an integrated approach to the irritable bowel syndrome. Aliment Pharmacol Ther 1999; 13(suppl 2):3-14.

266. Svedlund J. Psychotherapy in irritable bowel syndrome: a controlled outcome study. Acta Psychiatr Scand 1983;67;(suppl 306):1-86.

267. Creed FH, Fernandes L, Guthrie E, Palmer S, Ratcliffe J, Read N, Rigby C, Thompson DG, Tomenson B. The cost-effectiveness of psychotherapy and SSRI antidepressants for severe irritable bowel syndrome (abstr). Gastroenterology 2001;120:A115.

268. Bennett P, Wilkinson S. A comparison of psychological and medical treatment of the irritable bowel syndrome. Br J Clin Psychol 1985;24:215-216.

269. Greene B, Blanchard EB. Cognitive therapy for irritable bowel syndrome. J Consult Clin Psychol 1994;62:576-582.

270. van Dulmen AM, Fennis JFM, Bleijenberg G. Cognitive-behavioral group therapy for irritable bowel syndrome: effects and long-term follow-up. Psychosom Med 1996;58:508-514.

271. Heymann-Mönnikes I, Arnold R, Florin I, Herda C, Melfsen S,
Mönnikes $\mathrm{H}$. The combination of medical treatment plus multicomponent behavioral therapy is superior to medical treatment alone in the therapy of irritable bowel syndrome. Am J Gastroenterol 2000;95:981-994.

272. Voirol MW, Hipolito J. Anthropo-analytical relaxation in irritable bowel syndrome: results 40 months later. Schweiz Med Wochenschr 1987;117:1117-1119.

273. Shaw G, Srivastava ED, Sadlier M, Swann P, James JY, Rhodes $J$. Stress management for irritable bowel syndrome: a controlled trial. Digestion 1991;50:36-42.

Address requests for reprints to: Chair, Clinical Practice Committee, AGA National Office, c/o Membership Department, 7910 Woodmont Avenue, 7th Floor, Bethesda, Maryland 20814. Fax: (301) 654-5920.

The Clinical Practice Committee acknowledges the following individuals whose critiques of this review paper provided valuable guidance to the authors: James E. Allison, M.D., Lisa Gangarosa, M.D., Richard G. Locke III, M.D., George F. Longstreth, M.D., Howard R. Mertz, M.D., and Amy Foxx-Orenstein, D.O.

The authors thank Carlar Blackman and Cathy Coleman for their invaluable assistance in the preparation of this manuscript. 